\title{
Article \\ Organoruthenium Complexes with Benzo-Fused Pyrithiones Overcome Platinum Resistance in Ovarian Cancer Cells
}

\author{
Jerneja Kladnik ${ }^{1}$, James P. C. Coverdale ${ }^{2}$, Jakob Kljun ${ }^{1} @$, Hilke Burmeister ${ }^{3}$, Petra Lippman ${ }^{3}$, \\ Francesca G. Ellis ${ }^{2}$, Alan M. Jones ${ }^{2} \mathbb{D}$, Ingo Ott ${ }^{3}$, Isolda Romero-Canelón ${ }^{2} * \mathbb{D}$ and Iztok Turel ${ }^{1, * \mathbb{D}}$ \\ 1 Faculty of Chemistry and Chemical Technology, University of Ljubljana, 1000 Ljubljana, Slovenia; \\ jerneja.kladnik@fkkt.uni-lj.si (J.K.); jakob.kljun@fkkt.uni-lj.si (J.K.) \\ 2 School of Pharmacy, Institute of Clinical Sciences, University of Birmingham, Birmingham B15 2TT, UK; \\ j.coverdale.1@bham.ac.uk (J.P.C.C.); FGE818@alumni.bham.ac.uk (F.G.E.); a.m.jones.2@bham.ac.uk (A.M.J.) \\ 3 Institute of Medicinal and Pharmaceutical Chemistry, Technische Universität Braunschweig, \\ 38106 Braunschweig, Germany; h.burmeister@tu-bs.de (H.B.); p.lippmann@tu-bs.de (P.L.); \\ ingo.ott@tu-bs.de (I.O.) \\ * Correspondence: i.romerocanelon@bham.ac.uk (I.R.-C.); iztok.turel@fkkt.uni-lj.si (I.T.)
}

Citation: Kladnik, J.; Coverdale, J.P.C.; Kljun, J.; Burmeister, H.; Lippman, P.; Ellis, F.G.; Jones, A.M.; Ott, I.; Romero-Canelón, I.; Turel, I. Organoruthenium Complexes with Benzo-Fused Pyrithiones Overcome Platinum Resistance in Ovarian Cancer Cells. Cancers 2021, 13, 2493. https://doi.org/10.3390/ cancers 13102493

Academic Editor: Alexandre Escargueil

Received: 12 April 2021

Accepted: 14 May 2021

Published: 20 May 2021

Publisher's Note: MDPI stays neutral with regard to jurisdictional claims in published maps and institutional affiliations.

Copyright: (c) 2021 by the authors. Licensee MDPI, Basel, Switzerland. This article is an open access article distributed under the terms and conditions of the Creative Commons Attribution (CC BY) license (https:// creativecommons.org/licenses/by/ $4.0 /)$
Simple Summary: Ovarian cancer is the fifth most common cancer in the developing world, with many front-line treatments combining paclitaxel with platinum-based anticancer agents cisplatin/carboplatin. However, increased incidence of platinum resistance demands the development of new chemotherapeutic agents. The aim of our study was to explore a new family of organoruthenium(II) pyrithione complexes for their efficacy towards platinum-resistant ovarian cancer cells. We confirmed that this new class of compounds remain highly potent towards platinum-insensitive cells and appear to work by a mechanism that is not common to platinum agents.

Abstract: Drug resistance to existing anticancer agents is a growing clinical concern, with many first line treatments showing poor efficacy in treatment plans of some cancers. Resistance to platinum agents, such as cisplatin, is particularly prevalent in the treatment of ovarian cancer, one of the most common cancers amongst women in the developing world. Therefore, there is an urgent need to develop next generation of anticancer agents which can overcome resistance to existing therapies. We report a new series of organoruthenium(II) complexes bearing structurally modified pyrithione ligands with extended aromatic scaffold, which overcome platinum and adriamycin resistance in human ovarian cancer cells. The mechanism of action of such complexes appears to be unique from that of cisplatin, involving $\mathrm{G}_{1}$ cell cycle arrest without generation of cellular ROS, as is typically associated with similar ruthenium complexes. The complexes inhibit the enzyme thioredoxin reductase (TrxR) in a model system and reduce cell motility towards wound healing. Importantly, this work highlights further development in our understanding of the multi-targeting mechanism of action exhibited by transition metal complexes.

Keywords: ruthenium; pyrithione; resistance to chemotherapy; cancer; ovarian; thioredoxin

\section{Introduction}

Ovarian cancer (OC), also known as "the silent killer", belongs to the most lethal gynecologic malignancies [1-5] and is the fifth most common cancer type in women in the developed world [6]. Although the mortality of patients with an early-stage OC is low, diagnosis at this stage is rather poor due to less obvious and non-specific symptoms. However, once diagnosed with the advanced OC, the survival rate decreases immensely, also due to development of chemotherapy resistance [5]. Thus far, five histological subtypes of OC are known, of which epithelial tumors are the most common, accounting for approximately 90\% [7]. Several genetic (BRCA1/2 gene mutations, DNA mismatched repair gene mutations) and epidemiological risk factors (age, obesity, talcum powder use/asbestos exposure) contribute to the development and the progression of OC $[5,8]$. 
Standard OC treatment includes surgery followed by chemotherapy, usually with platinum- (cisplatin, carboplatin) in combination with taxane-based compounds (paclitaxel, docetaxel). As OC is usually discovered at an advanced stage, complete surgical debulking is necessary to maximize the efficacy of subsequent chemotherapy and minimize the likelihood of disease recurrence. Nevertheless, the recurrence rate remains high and is often associated with the development of platinum resistance [7,9]. Intrinsic or acquired multidrug resistance (MDR) to chemotherapeutic agents in patients with advanced OC is responsible for almost $90 \%$ of deaths [10]. Cancer cells are capable of developing multiple MDR mechanisms, such as increased xenobiotic metabolism by phase I and II drug-metabolizing enzymes (e.g., cytochromes and glutathione-S-transferase), elevated drug efflux (e.g., ATP-binding cassette proteins such as P-glycoprotein (P-gp)), gene mutations (e.g., very common are tumor suppressor gene TP53 and $B C R-A B L$ gene mutations), elevated production of growth factors (e.g., interleukins, protein kinases, extracellular matrix proteins), and enhanced DNA repair capacity [11]. In OC, overexpression of the efflux protein P-gp is frequently reported, which enables chemotherapeutic agents to be excreted out of the cell, consequently preventing drugs used from interacting with their targets and causing cancer cell death. In addition, OC stem cells, non-coding RNA, increased autophagy, and tumor heterogeneity also contribute to MDR [10].

Platinum drugs are obviously not efficient enough to combat this treacherous disease alone. In response, research groups are now exploring new metal complex architectures based on chemically similar neighboring transition metals, including iridium [12], osmium [13-15], and rhodium [16,17]. Besides, complexes based on ruthenium gained significant attention in recent years. Pre-clinical studies and clinical trials of key ruthenium(III) complexes, $\mathrm{KP} 1019$ ((IndH)[trans- $\left.\mathrm{RuCl}_{4}(\mathrm{Ind})_{2}\right]$, Ind = indazole), its sodium salt $\mathrm{KP} 1339$ (Na[trans-RuCl$\left.\left.{ }_{4}(\mathrm{Ind})_{2}\right]\right)$ [18], and NAMI-A ((ImH)[trans-RuCl $\left.{ }_{4}(\mathrm{dmso}-\mathrm{S})(\mathrm{Im})\right], \mathrm{Im}$ $=$ imidazole) $[19,20]$ demonstrated the potential ruthenium compounds offer in the fight against platinum resistance, inspiring the development of future generations of rutheniumbased therapies [21-24]. Importantly, the in-cell mechanism of action of many $\mathrm{Ru}(\mathrm{II})$ or $\mathrm{Ru}(\mathrm{III})$ complexes is not solely, or in some cases not at all, dependent on DNA binding interactions, unlike platinum therapies. In fact, many ruthenium complexes were shown to be multitargeting, for instance, by perturbing cellular redox homeostasis, targeting subcellular organelles [25], or disrupting the processes of cell invasion and migration [26].

In the preclinical stage, some ruthenium complexes were also tested on various OC cell lines. Some ruthenium(III) complexes were evaluated in vitro on cisplatin-sensitive and -resistant rat ovarian tumors [27]. Furthermore, organoruthenium(II) complexes with $\mathrm{N}, \mathrm{N}$ - [22,28-31], O,O- [32-36], N,S- [37], and S-ligands [38] were extensively studied on OC cell lines. Due to the emergence of new therapeutics for the OC treatment, the aim of this study was to thoroughly investigate organoruthenium(II) complexes (1a-b and $\mathbf{2 a}-\mathbf{b}$, Figure 1C) with isostructural $O, S$-pyrithione type ligands with extended quinoline and isoquinoline scaffolds, namely 2-hydroxyisoquinoline-1 $(2 \mathrm{H})$-thione and 1-hydroxyquinoline-2$(1 H)$-thione (a and $\mathbf{b}$, respectively; Figure 1B), for their anticancer properties for this cancer type. Pyrithione (Figure 1A) is a common name for the organic compound that tautomerizes as either 1-hydroxypyridine-2(1H)-thione (predominant form) or 2-mercaptopyridine $\mathrm{N}$ oxide and has high affinity to most transition metal ions via oxygen and sulphur atoms [39]. In recent years, the Turel group began to focus on the study of organoruthenium(II) complexes with pyrithione and its analogues for their biological properties, mainly anticancer [40-42] and, to some extent, antineurodegenerative [43,44]. In this study, we show that condensation of the benzene ring to the pyrithione scaffold increases the activity of complexes towards various ovarian cancer cell lines, including resistant ones. After screening of prepared compounds for their antiproliferative properties against various cancer cell lines, compound 1a (Figure 1C) was selected for further comprehensive investigation of the mechanisms of action at the cellular level against ovarian cancer cell line A2780, including thioredoxin reductase inhibition, induction of reactive oxygen species, evaluation 
of mitochondrial function, cell cycle analysis, induction of apoptosis, wound healing assay, and colony formation assay.

A)

pyrithione<smiles></smiles>

B) pyrithione analogues with extended aromatic scaffold<smiles></smiles>

$\mathbf{a}$<smiles>On1c(=S)ccc2ccccc21</smiles>

b
C) organoruthenium(II) pyrithionato chlorido/pta complexes
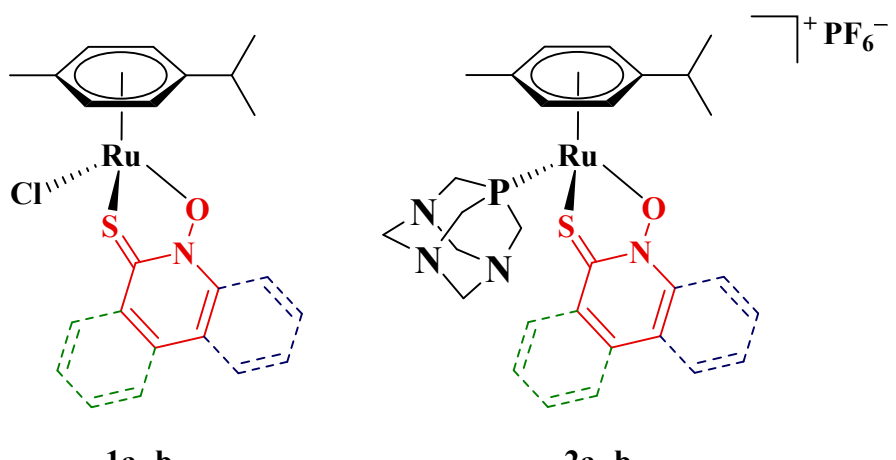

$\mathbf{2 a}-\mathbf{b}$

Figure 1. (A) Pyrithione and its tautomeric forms. (B) Pyrithione analogues with extended aromaticity $\mathbf{a}-\mathbf{b}$ and (C) their organoruthenium(II) chlorido $\mathbf{1 a}-\mathbf{b}$ and pta (1,3,5-triaza-7-phosphaadamantane) complexes $\mathbf{2 a -} \mathbf{a}$.

\section{Materials and Methods}

\subsection{Chemicals}

Starting materials and other reagents as well as the solvents for the synthesis of ligands $\mathbf{a}-\mathbf{b}$ and complexes $\mathbf{1} \mathbf{a}-\mathbf{b}$ and $\mathbf{2} \mathbf{a}-\mathbf{b}$ were purchased from commercial suppliers (Fluorochem, Hadfield, UK; Strem Chemicals, Inc., Newburyport, MA, USA; Merck, Darmstadt, Germany; Honeywell, Muskegon, MI, USA) and used as received, except from $\mathrm{CHCl}_{3}$ used for $\mathrm{N}$-oxidation, which was dried over $\mathrm{Na}_{2} \mathrm{SO}_{4}$ prior to use. Pta ligand (1,3,5-triaza7-phosphaadamantane) was prepared as reported [45]. The progress of the reaction was followed by pre-coated TLC sheets ALUGRAM ${ }^{\circledR}$ SIL G/UV254 (Macherey-Nagel, Düren, Germany) under UV light, and column chromatography was carried out on Merck Silica gel $60(35-70 \mu \mathrm{m})$ as stationary phase.

RPMI-1640 culture medium, penicillin/streptomycin concentrate, glutamine ( $2 \mathrm{mM}$ solution), trypsin-EDTA, phosphate-buffered saline (PBS), hydrogen peroxide, propidium iodide (PI), RNAse, 2', $7^{\prime}$-dichlorofluorescein diacetate (DCFH-DA), thiazolyl blue tetrazolium bromide (MTT), dimethyl sulfoxide (DMSO), RNAse, Annexin-V-FITC, and tert-butyl hydroperoxide (TBHP) used in biological experiments were purchased from Sigma Aldrich (St. Louis, MO, USA). The 96-well plates assays were carried out using a FLUOStar Omega microplate reader. Microscopy images were obtained using a EVOS PL system. Flow cytometry was carried out using a Beckman Coulter Cytoflex.

\subsection{Physicochemical Characterization}

${ }^{1} \mathrm{H}$ and ${ }^{31} \mathrm{P}$ NMR spectra were obtained with Bruker Avance III 500 spectrometer at room temperature at $500 \mathrm{MHz}$ and $202 \mathrm{MHz}$, respectively. Chemical shifts $(\delta)$ are reported in ppm. ${ }^{1} \mathrm{H}$ NMR spectra are referenced to residual peaks of NMR solvent $\mathrm{CD}_{2} \mathrm{Cl}_{2}$ or $\mathrm{D}_{2} \mathrm{O}$ at 5.32 (referenced against the central line of triplet) or $4.79 \mathrm{ppm}$, respectively, and chemical shifts of ${ }^{31} \mathrm{P}$ NMR spectra relative to external standard. The multiplicities are abbreviated as $\mathrm{s}=$ singlet, $\mathrm{d}=$ doublet, $\mathrm{dd}=$ doublet of the doublets, sept $=$ septet, and $\mathrm{m}=$ multiplet. Coupling constants $(J)$ are given in Hz. MestReNova version 11.0.4 was used for NMR data processing. Infrared spectra were recorded with Bruker FTIR Alpha Platinum ATR spectrometer. High resolution mass spectra (HRMS) were carried out on an Agilent 6224 Accurate Mass TOF LC/MS instrument. Elemental analyses were obtained on a Perkin-Elmer 2400 II instrument $(\mathrm{C}, \mathrm{H}, \mathrm{N})$. UV-Vis spectra of complexes were obtained on PerkinElmer LAMBDA 750 UV/Vis/near-IR spectrophotometer and UV- 
Vis stability spectra on UV-Vis spectrophotometer UV-2600 Shimadzu. X-ray diffraction data were collected on an Oxford Diffraction SuperNova diffractometer with $\mathrm{Mo} / \mathrm{Cu}$ microfocus X-ray source $\left(\mathrm{K}_{\alpha}\right.$ radiation, $\left.\lambda_{\mathrm{Mo}}=0.71073 \AA, \lambda_{\mathrm{Cu}}=1.54184 \AA\right)$ with mirror optics and an Atlas detector at 150(2) K. The structures were solved in Olex ${ }^{2}$ graphical user interface [46] by direct methods implemented in SHELXT and refined by a full-matrix least-squares procedure based on $\mathrm{F}^{2}$ using SHELXL [47]. All non-hydrogen atoms were refined anisotropically. The hydrogen atoms were placed at calculated positions and treated using appropriate riding models. The crystal structures were submitted to the CCDC and were allocated the deposition numbers 2065161-2 065162 for ligand a and complex 2b, respectively. Cyclic voltammetry (CV) was performed using an Autolab PGSTAT100N potentiostat, processed with Nova 2.0 software, cleaned with Microsoft Excel, and graphs were created using SigmaPlot 13.0. Measurements for complexes 1a and $2 \mathbf{a}$ and ligand a $\left(1.0 \mathrm{mM}, \mathrm{CH}_{3} \mathrm{CN}\right.$ containing tetrabutylammonium hexafluorophosphate $(0.1 \mathrm{M})$ as supporting electrolyte) were carried out using degassed solutions under nitrogen, and voltammograms were scanned from $+2.0 \mathrm{~V}$ to $-2.0 \mathrm{~V}$. Alternatively, voltammograms were scanned from $+0.8 \mathrm{~V}$ to $-0.8 \mathrm{~V}$ to mimic biological redox potentials. In a typical electrochemical experimental set up, a three-electrode system was used: a glassy carbon electrode as the working electrode, $\mathrm{Ag} / \mathrm{AgCl}$ as the reference electrode $\left(\left(+7 \mathrm{mV}\right.\right.$ vs. $\left.\mathrm{Fc}^{+} / \mathrm{Fc}\right)$ $+205 \mathrm{mV}$ vs. N.H.E.), and platinum wire as the counter electrode. For each electrode, CV was performed at a $v=100 \mathrm{mVs}^{-1}$.

\subsection{Syntheses of Ligands and Complexes}

Ligands $\mathbf{a}-\mathbf{b}$ as well as organoruthenium(II) chlorido complexes $\mathbf{1} \mathbf{a}-\mathbf{b}$ were resynthesized according to published protocols [44,48], while organoruthenium(II) pta complexes 2a-b were newly prepared following our published protocol [41] as described below (general synthesis pathways presented in Supplementary Materials, Figure S1) and physiochemically characterized $\left({ }^{1} \mathrm{H}\right.$ NMR spectra can be found in Supplementary Materials, Figures S13 and S14).

Appropriate chlorido complex 1a-b (50 mg, $0.112 \mathrm{mmol}, 1 \mathrm{~mol}$. equiv.) was dissolved in dichloromethane $(30 \mathrm{~mL})$ and finely ground pta ligand $(0.168 \mathrm{mmol}, 1.5 \mathrm{~mol}$. equivalents) as well as $\mathrm{NH}_{4} \mathrm{PF}_{6}(0.168 \mathrm{mmol}, 1.5 \mathrm{~mol}$. equivalents) were added and stirred in the dark for $48 \mathrm{~h}$ at ambient temperature. After the reaction was completed, the solvent was partly evaporated and filtered through a pad of Celite to remove side product $\mathrm{NH}_{4} \mathrm{Cl}$ and excess of $\mathrm{NH}_{4} \mathrm{PF}_{6}$ and pta. Then, the mother liquor was concentrated on a rotary evaporator to approximately $2 \mathrm{~mL}$. Cold diethyl ether was added to the oily residue, which resulted in precipitation of orange solid, which was washed with diethyl ether and dried at $45^{\circ} \mathrm{C}$ overnight.

[ $\eta^{6}-p$-Cymene) $\mathrm{Ru}(\mathrm{II})$ (2-hydroxyisoquinoline- $1(2 H)$-thionato)pta]PF 6 (2a). Yield: $65 \%$. ${ }^{1} \mathrm{H}$ NMR $\left(500 \mathrm{MHz},\left(\mathrm{CD}_{2} \mathrm{Cl}_{2}\right)\right): \delta=8.62-8.58(\mathrm{~m}, 1 \mathrm{H}, \mathrm{Ar}-\mathrm{H}$ a) $)$ 7.85-7.80 $(\mathrm{m}, 2 \mathrm{H}, \mathrm{Ar}-\mathrm{H}$ a), 7.80-7.72 (m, 2H, Ar-H a), $7.33(\mathrm{~d}, 1 \mathrm{H}, J=7.3 \mathrm{~Hz}, \mathrm{Ar}-\mathrm{H}$ a), $5.98(\mathrm{~d}, 1 \mathrm{H}, J=6.1 \mathrm{~Hz}$, Ar- $H$ cym), $5.90(\mathrm{~d}, 1 \mathrm{H}, J=6.1 \mathrm{~Hz}, \mathrm{Ar}-H \mathrm{cym}), 5.72(\mathrm{~d}, 1 \mathrm{H}, J=6.1 \mathrm{~Hz}, \mathrm{Ar}-H \mathrm{cym}), 5.59$ (d, $1 \mathrm{H}, J=6.1 \mathrm{~Hz}, \mathrm{Ar}-H \mathrm{cym}), 4.44$ (s, 6H, H-pta), 4.13 (dd, 3H, $J=15.1,3.6 \mathrm{~Hz}, H-$ pta), 3.98 (dd, 3H, $J=15.1,3.6 \mathrm{~Hz}, \mathrm{H}-\mathrm{pta}), 2.66$ (sept, $\left.1 \mathrm{H}, J=6.9 \mathrm{~Hz}, \mathrm{Ar}-\mathrm{CH}\left(\mathrm{CH}_{3}\right)_{2} \mathrm{cym}\right), 2.16$ $\left(\mathrm{s}, 3 \mathrm{H}, \mathrm{Ar}-\mathrm{CH}_{3} \mathrm{cym}\right), 1.28\left(\mathrm{~d}, 3 \mathrm{H}, J=6.9 \mathrm{~Hz}, \mathrm{Ar}-\mathrm{CH}\left(\mathrm{CH}_{3}\right)_{2} \mathrm{cym}\right), 1.25(\mathrm{~d}, 3 \mathrm{H}, J=6.9 \mathrm{~Hz}$, $\left.\mathrm{Ar}-\mathrm{CH}\left(\mathrm{CH}_{3}\right)_{2} \mathrm{cym}\right) \mathrm{ppm} .{ }^{31} \mathrm{P}$ NMR $\left(202 \mathrm{MHz}, \mathrm{CD}_{2} \mathrm{Cl}_{2}\right): \delta=-31.86$ (P-pta), -144.31 (sept, $\left.J_{\mathrm{PF}}=712 \mathrm{~Hz}, P \mathrm{~F}_{6}\right) \mathrm{ppm}$. IR selected bands ( $\left.\mathrm{cm}^{-1}, \mathrm{ATR}\right): 2971,974,947,836,801,742,670$, 580, 557, 480. UV-Vis $\left(\lambda(\mathrm{nm})\left(\varepsilon\left(\mathrm{L} \mathrm{mol}^{-1} \mathrm{~cm}^{-1}\right)\right) c=5 \times 10^{-5} \mathrm{M}, \mathrm{MeOH}\right): 315$ (12268), 393 (4822). ESI-HRMS $\left(\mathrm{CH}_{3} \mathrm{CN}\right) \mathrm{m} / \mathrm{z}$ for $\left[\mathrm{M}-\mathrm{PF}_{6}\right]^{+}$(found (calcd)): 569.1078 (569.1078). Anal. Calcd for $\mathrm{C}_{25} \mathrm{H}_{32} \mathrm{~F}_{6} \mathrm{~N}_{4} \mathrm{OP}_{2}$ RuS: C, 42.08; $\mathrm{H}, 4.52 ; \mathrm{N}, 7.85$. Found: $\mathrm{C}, 42.23 ; \mathrm{H}, 4.52 ; \mathrm{N}, 7.49$.

[( $\eta^{6}-p$-Cymene) $\mathrm{Ru}(\mathrm{II})$ (1-hydroxyquinoline-2-(1H)-thionato)pta] $\mathrm{PF}_{6}(\mathbf{2 b})$. Yield: $56 \%$. ${ }^{1} \mathrm{H}$ NMR $\left(500 \mathrm{MHz},\left(\mathrm{CD}_{2} \mathrm{Cl}_{2}\right)\right): \delta=8.29(\mathrm{~d}, 1 \mathrm{H}, J=8.6 \mathrm{~Hz}, \mathrm{Ar}-\mathrm{H} \mathrm{b}), 7.85-7.78(\mathrm{~m}, 2 \mathrm{H}, \mathrm{Ar}-\mathrm{H}$ b), $7.69(\mathrm{~d}, 1 \mathrm{H}, J=8.9 \mathrm{~Hz}, \mathrm{Ar}-H \mathrm{~b}), 7.61-7.56(\mathrm{~m}, 1 \mathrm{H}, \mathrm{Ar}-H \mathrm{~b}), 7.47(\mathrm{~d}, 1 \mathrm{H}, J=8.9 \mathrm{~Hz}, \mathrm{Ar}-H$ b), $6.02(\mathrm{~d}, 1 \mathrm{H}, J=6.1 \mathrm{~Hz}, \mathrm{Ar}-H \mathrm{cym}), 5.95(\mathrm{~d}, 1 \mathrm{H}, J=6.1 \mathrm{~Hz}, \mathrm{Ar}-H \mathrm{cym}), 5.73(\mathrm{~d}, 1 \mathrm{H}$, $J=6.1 \mathrm{~Hz}, \mathrm{Ar}-H \mathrm{cym}), 5.58(\mathrm{~d}, 1 \mathrm{H}, J=6.1 \mathrm{~Hz}, \mathrm{Ar}-H \mathrm{cym}), 4.43$ (s, 6H, H-pta), 4.10 (dd, 3H, 
$J=15.1,3.5 \mathrm{~Hz}, H$-pta), 3.98 (dd, $3 \mathrm{H}, J=15.1,3.5 \mathrm{~Hz}, H$-pta), 2.66 (sept, $1 \mathrm{H}, J=6.9 \mathrm{~Hz}$, $\left.\mathrm{Ar}-\mathrm{CH}\left(\mathrm{CH}_{3}\right)_{2} \mathrm{cym}\right), 2.17\left(\mathrm{~s}, 3 \mathrm{H}, \mathrm{Ar}-\mathrm{CH}_{3} \mathrm{cym}\right), 1.31\left(\mathrm{~d}, 3 \mathrm{H}, J=6.9 \mathrm{~Hz}, \mathrm{Ar}-\mathrm{CH}\left(\mathrm{CH}_{3}\right)_{2} \mathrm{cym}\right)$, $1.25\left(\mathrm{~d}, 3 \mathrm{H}, J=6.9 \mathrm{~Hz}, \mathrm{Ar}-\mathrm{CH}\left(\mathrm{CH}_{3}\right)_{2} \mathrm{cym}\right) \mathrm{ppm} .{ }^{31} \mathrm{P} \mathrm{NMR}\left(202 \mathrm{MHz}, \mathrm{CD}_{2} \mathrm{Cl}_{2}\right): \delta=-31.73$ (P-pta), -144.29 (sept, $\left.J_{\mathrm{PF}}=712 \mathrm{~Hz}, P \mathrm{~F}_{6}\right)$ ppm. IR selected bands ( $\mathrm{cm}^{-1}$, ATR): 2946, 1014, $979,946,830,808,739,578,556,451$. UV-Vis $\left(\lambda(\mathrm{nm})\left(\varepsilon\left(\mathrm{L} \mathrm{mol}^{-1} \mathrm{~cm}^{-1}\right)\right) c=5 \times 10^{-5} \mathrm{M}\right.$, $\mathrm{MeOH}$ ): 292 (20472), 357sh (5604), 412 (4322). ESI-HRMS $\left(\mathrm{CH}_{3} \mathrm{CN}\right) \mathrm{m} / z$ for $\left[\mathrm{M}-\mathrm{PF}_{6}\right]^{+}$(found (calcd)): 569.1083 (569.1078). Anal. Calcd for $\mathrm{C}_{25} \mathrm{H}_{32} \mathrm{~F}_{6} \mathrm{~N}_{4} \mathrm{OP}_{2} \mathrm{RuS}: \mathrm{C}, 42.08 ; \mathrm{H}, 4.52 ; \mathrm{N}, 7.85$. Found: C, 41.63; H, 4.79; N, 7.87 .

\subsection{Aqueous Stability}

For NMR stability, approximately $4 \mathrm{mg}$ of compound was first dissolved in $\left(\mathrm{CD}_{3}\right)_{2} \mathrm{SO}$ to which $\mathrm{D}_{2} \mathrm{O}$ was added to obtain $5 \%\left(\mathrm{CD}_{3}\right)_{2} \mathrm{SO} / \mathrm{D}_{2} \mathrm{O}$ final solution $(600 \mu \mathrm{L})$. In case of the stability experiments with $\mathrm{NaCl}, \mathrm{NaCl}$ was first dissolved in $\mathrm{D}_{2} \mathrm{O}$, and a latter solution was consequently added to $\left(\mathrm{CD}_{3}\right)_{2} \mathrm{SO}$ solution with the complex to obtain $5 \%\left(\mathrm{CD}_{3}\right)_{2} \mathrm{SO} / \mathrm{D}_{2} \mathrm{O}$ final solution containing $140 \mathrm{mM} \mathrm{NaCl}(600 \mu \mathrm{L}) .{ }^{1} \mathrm{H}$ NMR spectra were recorded immediately after the preparation of the solutions and later at the selected timepoints.

UV-Vis stability was studied over $24 \mathrm{~h}$ using UV-visible spectroscopy in biologically relevant matrixes: a) PBS, b) RPMI-1640, c) fully prepared RPMI-1640 which included the addition of $10 \% v / v$ fetal calf serum and $1 \% v / v$ pen/strep antibiotics, and d) human blood plasma. DMSO stock solutions of tested complexes were prepared and further diluted in the mentioned matrixes. UV-Vis spectra were obtained immediately after the preparation of solutions and after $24 \mathrm{~h}$ between 250 and $900 \mathrm{~nm}$ using single beam scans with background correction. Between these two measurement timepoints, samples were kept in sealed cuvettes at $37^{\circ} \mathrm{C}$.

\subsection{Human Cancer Cell Culture}

Human cells lines (A2780, SW626, SKOV3, A2780Cis, A2780ADR, A549, HEPG2, OE19, PC3, HCT116) were purchased from the European Collection of Cell Cultures (ECACC) and tested at regular intervals to confirm mycoplasma free status. Cells were grown as adherent monolayers using RPMI-1640 culture medium supplemented with $10 \% v / v$ fetal calf serum, $1 \% v / v$ penicillin/streptomycin antibiotics, and $1 \% v / v 2 \mathrm{mM}$ glutamine. Cells were maintained using 25 or $75 \mathrm{~cm}^{2}$ flasks at $37^{\circ} \mathrm{C}$ in a humidified atmosphere containing $5 \% \mathrm{CO}_{2}$ and passaged at regular intervals using trypsin-EDTA upon reaching $80-90 \%$ confluence.

\subsection{Determination of Antiproliferative Activity}

Using flat-bottom 96 -well plates, $5 \times 10^{3}$ cells were seeded per well in drug-free media and incubated at $37^{\circ} \mathrm{C} \mathrm{K}$ for $48 \mathrm{~h}$. Prior to the treatment of cells, a stock solution of a test compound was prepared using a 1:1 mixture of cell culture medium and saline $(0.9 \%)$ and a starting concentration of $5 \% v / v$ DMSO to aid complex solubility. Serial dilutions of the stock solution were prepared to ensure the final working DMSO concentration did not exceed $0.5 \% v / v$. Cells were treated with six concentrations of test complex between 200 and $0.01 \mu \mathrm{M}$ for $24 \mathrm{~h}$ at $37^{\circ} \mathrm{C}$, then the supernatant solution was aspirated, cells were washed with PBS, and cells were re-incubated in fresh (drug-free) media. After $72 \mathrm{~h}$ further incubation at $37^{\circ} \mathrm{C}$ (so-called "recovery time"), cell viability was determined using the MTT assay ( $4 \mathrm{~h}$ dark exposure to MTT reagent). After this time, dye was solubilized in DMSO, and absorbance measurements were obtained using a microplate reader. Cell viabilities and respective $\mathrm{IC}_{50}$ concentrations (the concentration of tested complex which caused $50 \%$ growth inhibition) were calculated relative to untreated controls as part of duplicate of triplicate experiments in two independent experiments.

\subsection{Induction of Apoptosis}

Briefly, $2 \times 10^{5} \mathrm{~A} 2780$ human ovarian cancer cells were seeded in flat-bottom 6-well plates and incubated at $37^{\circ} \mathrm{C}$ for $24 \mathrm{~h}$ in a $\mathrm{CO}_{2}$ humidified atmosphere. Cells were treated 
with $1 \mu \mathrm{M}$ concentrations of complex 1a in cell culture media (DMSO not exceeding $0.5 \%$ $v / v)$, prepared as described previously. After $24 \mathrm{~h}$ incubation, the supernatant solution was removed by aspiration, and adherent cells were washed with PBS and collected using trypsin. After quenching of trypsin activity with culture media (containing FCS), cells were resuspended as a single cell solution in buffer containing propidium iodide (PI, Ex. $560 \mathrm{~nm}$, Em. $595 \mathrm{~nm}$ ) and Annexin-V-FITC conjugate (Ex. $485 \mathrm{~nm}$, Em. $535 \mathrm{~nm}$ ). Separately, negative (untreated) and positive ( $1 \mu \mathrm{g} / \mathrm{mL}$ staurosporine) control samples were prepared. No cellular fixation protocols were employed to circumvent non-specific binding of Annexin-V-FITC. Samples were analyzed using flow cytometry with gating determined using positive and negative control samples. The experiment was carried out as three independent biological replicates.

\subsection{Cell Cycle Analysis}

Briefly, $1 \times 10^{6}$ A2780 human ovarian cancer cells were seeded using flat-bottom 6-well plates and incubated at $37^{\circ} \mathrm{C}$ for $24 \mathrm{~h}$. Cells were treated with $1 \mu \mathrm{M}$ concentrations of complex 1a in cell culture media (DMSO not exceeding $0.5 \% v / v$ ), prepared as described previously. After $24 \mathrm{~h}$ incubation at $37^{\circ} \mathrm{C}$, the supernatant solution was removed by aspiration, and adherent cells were washed with PBS and collected using trypsin. Negative (untreated) control samples were also prepared. After quenching of trypsin activity with culture media (containing FCS), cells were resuspended in ice-cold ethanol for $2 \mathrm{~h}$. Ethanol was removed by centrifugation, and cell pellets were suspended in fixation buffer containing propidium iodide (PI, Ex. $560 \mathrm{~nm}, \mathrm{Em} .595 \mathrm{~nm}$ ) and RNAse A. Cells were analyzed using flow cytometry, and data were processed using Flowjo for Windows. Experiments were carried out as three independent biological replicates.

\subsection{Wound Healing Assay}

Briefly, 24-well plates were seeded using $1 \times 10^{4}$ A2780 human ovarian cancer cells per well and incubated at $37^{\circ} \mathrm{C}$ for $24 \mathrm{~h}$. After this time, a sterile pipette tip was used to create two "wounds" per well, and cells were treated with $1 \mu \mathrm{M}$ complex $1 \mathrm{a}$ for $24 \mathrm{~h}$. The supernatant solution was aspirated, and cells were washed with PBS and stained using crystal violet solution ( $10 \%$ ethanol). After staining, excess stain was removed using PBS, and cells were visualized using a transmission microscope using $4 \times$ optical zoom. Values were calculated out of 36 random measurements of three wounds (12 measurements in each wound).

\subsection{Colony Formation Assay}

A2780 cancer cells were seeded in P100 flasks at a density of $1 \times 10^{3}$ and incubated for $24 \mathrm{~h}$ at $37^{\circ} \mathrm{C}$ before administration of $1 \mu \mathrm{M}$ concentration of complex $1 \mathrm{a}$ in culture medium (DMSO not exceeding $0.5 \% v / v$ ), prepared as described previously. After this time, cells were washed and allowed a further seven days of growth at $37^{\circ} \mathrm{C}$ in fresh media. Then, colonies were counted. This experiment was carried out in duplicate with independent triplicate experiments.

\subsection{Induction of Reactive Oxygen Species (ROS)}

Briefly, $1 \times 10^{4}$ A2780 human ovarian cancer cells were seeded using 96-well black plates and incubated at $37^{\circ} \mathrm{C}$ for $24 \mathrm{~h}$ in a humidified atmosphere. Cells were treated with $1 \mu \mathrm{M}$ concentrations of complex 1a in cell culture media (DMSO not exceeding $0.5 \% v / v$ ), prepared as described previously. After $24 \mathrm{~h}$ incubation at $37^{\circ} \mathrm{C}$, the supernatant solution was removed by aspiration, adherent cells washed with PBS, and to each well was added $100 \mu \mathrm{L}$ of $50 \mu \mathrm{M}$ of $2^{\prime}, 7^{\prime}$-dichlorofluorescein diacetate (DCFH-DA), after which time, plates were incubated in the dark for $2 \mathrm{~h}$. After staining, cells were washed thoroughly with PBS to remove excess stain before adding ROS inducers to positive control samples $(1 \mathrm{mM}$ hydrogen peroxide or $0.5 \mathrm{mM}$ tert-butyl hydroperoxide) for $2 \mathrm{~h}$ in the dark. Fluorescence readings were obtained using a microplate reader $\left(\lambda_{\mathrm{Ex}}=485 \mathrm{~nm}, \lambda_{\mathrm{Em}}=530 \mathrm{~nm}\right)$. Additional 
control samples included negative (untreated) controls, controls only treated with metal complexes (to eliminate auto-fluorescence), and complex-treated cells with ROS inducers. Data were obtained as biological triplicates. Generation of ROS was also investigated using fluorescence microscopy. Samples were prepared as described for quantification above with the following modification: cells were seeded using 8-well microscopy chambers using $5 \times 10^{4}$ cells per well. Measurements were obtained using an EVOS FL microscope.

\subsection{Evaluation of Mitochondrial Function}

Briefly, $5 \times 10^{3}$ A2780 human ovarian cancer cells were seeded in 8-well microscopy chambers and incubated at $37^{\circ} \mathrm{C}$ for $24 \mathrm{~h}$. Cells were treated with $1 \mu \mathrm{M}$ concentrations of complex 1a in cell culture media (DMSO not exceeding $0.5 \% v / v$ ), prepared as described previously. After $24 \mathrm{~h}$ incubation at $37^{\circ} \mathrm{C}$, the supernatant solution was removed by aspiration, and adherent cells washed with PBS and stained using DAPI/Rhodamine 123 (Rh-123) in buffer for $1 \mathrm{~h}$. This experiment included negative (untreated) controls. Measurements were obtained as biological triplicates using an EVOS FL microscope.

\subsection{Thioredoxin Reductase Assay}

Assay was carried out as in previously reported detailed protocols $[49,50]$. In short, commercially available rat liver TrxR (Sigma-Aldrich, St. Louis, MO, USA) was exposed to graded concentrations of the test compounds over $75 \mathrm{~min}$. After this exposure period, the reduction of 5,5'-dithiobis (2-nitrobenzoic acid) mediated by NADPH and TrxR to 5-thio-2nitrobenzoic acid was monitored photometrically at $405 \mathrm{~nm}$. The $\mathrm{IC}_{50}$ values represent the concentrations, which were required to reduce the enzyme catalyzed turnover by $50 \%$.

\subsection{Cellular Accumulation of Ruthenium}

Briefly, $1 \times 10^{6}$ cells were seeded using P100 plates and incubated at $37^{\circ} \mathrm{C}$ for $24 \mathrm{~h}$. Cells were treated with $\mathrm{IC}_{50}$ concentrations of complex 1a or $2 \mathbf{a}$ in cell culture media (DMSO not exceeding $0.5 \% v / v$ ), prepared as described previously. After $24 \mathrm{~h}$ incubation at $37^{\circ} \mathrm{C}$, the supernatant solution was removed by aspiration, and adherent cells were washed with PBS and harvested using trypsin. Trypsin activity was quenched using culture medium (containing FCS), cells were counted, and cell pellets were obtained by centrifugation. Cell pellets were re-washed with PBS to remove excess culture medium and re-centrifuged to afford the final cell pellet for analysis. The protein content of the cell pellets was determined by the Bradford method, and the ruthenium levels were measured using a high-resolution continuum source atomic absorption spectrometer (HRCS-AAS; contrAA 700 AnalytikJena) according to previously reported protocols $[50,51]$.

\subsection{Statistical Analysis}

In all cases, independent two-sample t-tests with unequal variances, Welch's tests, were carried out to establish statistical significance of the variations $\left(p<0.01\right.$ for ${ }^{*}$, and $p<0.05$ for $\left.^{*}\right)$.

\section{Results and Discussion}

\subsection{Syntheses and Crystal Structures of the Ligands and Complexes}

Compounds that were evaluated for their anticancer properties are presented in Figure 1 (B-ligands, C-complexes). Isostructural ligands $\mathbf{a}$ and $\mathbf{b}$ (Figure 1B) are isoquinoline and quinoline-derived pyrithione analogues, prepared in a two-step synthesis, involving $N$-oxidation followed by thiolation (Figure S1A) $[44,48]$. With ligands in hand organoruthenium(II) chlorido complexes $\mathbf{1 a}-\mathbf{b}$ (Figure 1C) were prepared by stirring ruthenium precursor $\left[\mathrm{Ru}(p \text {-cymene }) \mathrm{Cl}_{2}\right]_{2}$, selected pyrithionato-ligand $\mathbf{a}$ or $\mathbf{b}$, and a base sodium methoxide in dichloromethane (Figure S1B). After the purification of reaction mixture by column chromatography, complexes $\mathbf{1 a}-\mathbf{b}$ were isolated upon precipitation from DCM/nheptane [44]. Reactions to afford organoruthenium(II) pta complexes $\mathbf{2 a - b}$ (Figure 1C; Figure S1B) were carried out using chlorido complexes $\mathbf{1 a}$ or $\mathbf{1 b}$, respectively, which were 
stirred with ammonium hexafluorophosphate $\left(\mathrm{NH}_{4} \mathrm{PF}_{6}\right)$ and ground pta ligand, both of which were present in excess. The role of $\mathrm{NH}_{4} \mathrm{PF}_{6}$ was to facilitate the abstraction of the chlorido ligand from ruthenium (II) species and the subsequent binding of the phosphine ligand pta. After the reaction was completed, the excesses of $\mathrm{NH}_{4} \mathrm{PF}_{6}$ and pta as well as the insoluble byproduct $\mathrm{NH}_{4} \mathrm{Cl}$ were filtered off through a pad of Celite, and the mother liquor was concentrated on a rotary evaporator. The addition of cold diethyl ether resulted in the precipitation of the yellow solid complexes, which were isolated by filtration.

Crystal structures of chlorido complexes $\mathbf{1 a}-\mathbf{b}$ were already reported [44]. However, we additionally obtained suitable crystals of ligand $\mathbf{a}$ and pta complex $\mathbf{2 b}$ for single crystal X-ray diffraction (Figure S2). Ligand a crystallized in the thione form (Figure 2), similar to all other previously reported pyrithione analogues [41]. The packing of molecules was characterized by the formation of dimers through $\mathrm{O}-\mathrm{H} \cdots \mathrm{S}$ hydrogen bonds of the thiohydroxamate functional groups and $\pi$-stacking interactions of the isoquinoline rings with the distance between planes defined by the 10 ring atoms of $3.403 \AA$ (Figure S3). The crystal structure of pta complex $\mathbf{2 b}$ showed pseudooctahedral geometry of the ruthenium (II) coordination sphere with the bidentately bound ligand $\mathbf{b}$ forming a cationic structure (Figure 2, Table S1).

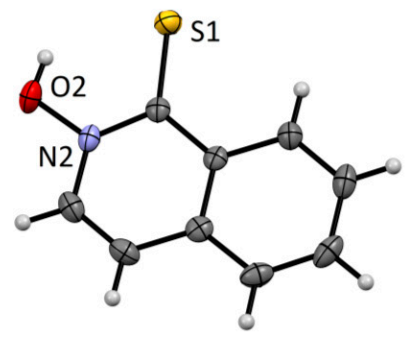

a
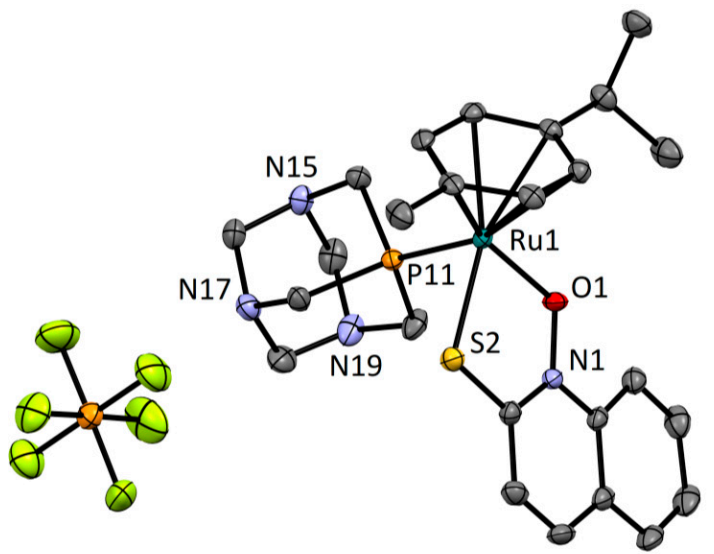

$2 \mathbf{b}$

Figure 2. Crystal structures of ligand a and pta complex $\mathbf{2 b}$. Thermal ellipsoids are drawn at $35 \%$ probability level.

\subsection{NMR Stability in Solution}

NMR stability studies were carried out for chlorido $\mathbf{1} \mathbf{a}-\mathbf{b}$ and pta $\mathbf{2} \mathbf{a}-\mathbf{b}$ complexes to follow possible structural changes in simplified aqueous solutions of $5 \%\left(\mathrm{CD}_{3}\right)_{2} \mathrm{SO} / \mathrm{D}_{2} \mathrm{O}$ in the presence or the absence of $140 \mathrm{mM} \mathrm{NaCl}$ (Figures S4-S11). The addition of the salt mimics high concentrations of extracellular fluids of the body, while studies in water allow observation of possible hydrolysis events. It is reported that $\mathrm{Ru}-\mathrm{Cl}$ bond in structurally similar complexes is prone to undergo substitution with the neutral water molecules and form positively charged $\mathrm{Ru}-\mathrm{OH}_{2}$ species which can further interact with biological targets [52]. Moreover, in our previous studies, we found that the behavior of various organoruthenium complexes in solutions depends on the type of the ligand and affects interactions with biomolecules and, consequently, their biological activity $[41,53,54]$.

Interestingly, ruthenium pyrithione chlorido complexes $1 \mathbf{a}$ and $\mathbf{1 b}$ were observed to remain stable in both water and saline solutions, with only minor release of $p$-cymene ligand (around 2\%) from the metal observed after $24 \mathrm{~h}$ (Figures S4-S7), and the chlorido complex remained the major species in solution. In contrast, ruthenium pta complexes $\mathbf{2 a}$ and $\mathbf{2 b}$ appeared less stable in both water and saline (Figures S8-S11), and after 4 days, the free $p$-cymene ligand dominated over those of the coordinated pta complex. Additionally, new peaks were identified (4.4-4.2 ppm) which can be likely attributed to an uncoordinated pta derivate (pta oxide, 1,3,5-triaza-7-phosphaadamantane-7-oxide) as previously described 
for similar pta complexes [41]. However, we cannot unambiguously confirm the presence of pta oxide, as these new peaks do not precisely coincide with a referenced spectrum of free pta oxide.

\subsection{Antiproliferative Activity}

We first established the anticancer activities of (iso)quinoline-derived pyrithione ligands $\mathbf{a}-\mathbf{b}$, their organoruthenium(II) chlorido $\mathbf{1} \mathbf{a}-\mathbf{b}$, and pta complexes $\mathbf{2} \mathbf{a}-\mathbf{b}$ towards six human cancer cell lines-A2780 (ovarian), A549 (lung), HCT116 (colorectal), OE19 (oesophageal), HEPG2 (hepatocellular), and PC3 (prostate)—compared to the established platinum anticancer agent, cisplatin. Our results demonstrate that organoruthenium(II) chlorido complexes $\mathbf{1} \mathbf{a}$ and $\mathbf{1 b}$ showed moderate antiproliferative activity across a panel of human cancer cell lines (Table 1), however, they were particularly active towards ovarian cancer cells ( $\left.\mathrm{IC}_{50} 1.0-2.2 \mu \mathrm{M}\right)$. Ligands $\mathbf{a}$ and $\mathbf{b}$ from which the complexes were derived also exhibited modest antiproliferative activities towards all tested cancer cell lines (Table 1), however, to a lesser extent than their chlorido complexes. The ruthenium $p$-cymene precursor $\left[\mathrm{Ru}(p \text {-cymene }) \mathrm{Cl}_{2}\right]_{2}$ of complexes $\mathbf{1 a}$ and $\mathbf{1 b}$ is known to be inactive towards cancer cells [22,55-58], and our group determined its activity on A2780 and A549 cells with similar results (Figure S15). Hence, the enhancement of ligand anticancer activity can be attributed to the formation of the new complex. In contrast, pta complexes $\mathbf{2 a}$ and $\mathbf{2} \mathbf{b}$ were found to be inactive towards all cell lines in the concentration range investigated. This is particularly interesting when considering the established mechanism of action (MoA) of some structurally-similar ruthenium and osmium piano stool complexes, for which hydrolysis and/or displacement of the metal-halide bond at the monodentate site is known to be crucial to in-cell activation $[59,60]$. It appears that the pta moiety disrupts this process, thereby significantly reducing the potency of these complexes compared to their chlorido analogues, $\mathbf{1 a}$ and $\mathbf{1 b}$. Interestingly, substitution of the chlorido ligand for pta in previously reported methyl-substituted pyrithione complexes did not affect anticancer activities [41], however, our data suggest that the nature of the monodentate ligand is of great importance in the MoA of ruthenium pyrithione complexes bearing an extended aromatic system.

Table 1. Antiproliferative activities of the prepared compounds towards six human cancer cell lines: A2780 (ovarian), A549 (lung), HCT116 (colorectal), OE19 (oesophageal), HEPG2 (hepatocellular), and PC3 (prostate).

\begin{tabular}{ccccccc}
\hline \multirow{2}{*}{ Compound } & $\mathbf{7}$ & \multicolumn{7}{c}{ IC $_{\mathbf{5 0}}(\mu \mathrm{M})[\mathbf{a}]$} \\
\cline { 2 - 7 } & $\mathbf{A 2 7 8 0}$ & $\mathbf{A 5 4 9}$ & HCT116 & OE19 & HEPG2 & PC3 \\
\hline $\mathbf{a}$ & $8.6 \pm 0.2$ & $11.6 \pm 0.8$ & $17.5 \pm 0.4$ & $12.1 \pm 0.4$ & $32.5 \pm 0.6$ & $16.5 \pm 0.3$ \\
\hline $\mathbf{1 a}$ & $1.0 \pm 0.08$ & $4.5 \pm 0.3$ & $14.3 \pm 0.9$ & $10.9 \pm 0.2$ & $29.5 \pm 0.3$ & $5.1 \pm 0.2$ \\
\hline $\mathbf{2 a}$ & $>50[\mathrm{~b}]$ & $>50[\mathrm{~b}]$ & $>50[\mathrm{~b}]$ & $>50[\mathrm{~b}]$ & $>50[\mathrm{~b}]$ & $>50[\mathrm{~b}]$ \\
\hline $\mathbf{b}$ & $12.4 \pm 0.6$ & $10.4 \pm 0.2$ & $15.1 \pm 0.4$ & $16.7 \pm 0.5$ & $29.1 \pm 0.9$ & $13.1 \pm 0.2$ \\
\hline $\mathbf{1 b}$ & $2.2 \pm 0.3$ & $5.8 \pm 0.5$ & $8.4 \pm 0.3$ & $11.4 \pm 0.6$ & $25.9 \pm 0.4$ & $3.9 \pm 0.6$ \\
\hline $\mathbf{2 b}$ & $>50[\mathrm{~b}]$ & $>50[\mathrm{~b}]$ & $>50[\mathrm{~b}]$ & $>50[\mathrm{~b}]$ & $>50[\mathrm{~b}]$ & $>50[\mathrm{~b}]$ \\
\hline Cisplatin & $1.2 \pm 0.3$ & $3.2 \pm 0.1$ & $5.2 \pm 0.3$ & $8.7+0.9$ & $5.7 \pm 0.9$ & $4.1 \pm 0.5$ \\
\hline
\end{tabular}

[a] Cellular viability determined using the MTT assay after $24 \mathrm{~h}$ drug exposure time at $37^{\circ} \mathrm{C}$ and $72 \mathrm{~h}$ recovery in drug-free media. [b] No activity observed in concentration range investigated.

Platinum therapies are widely used in the first line treatment of ovarian cancers, however, resistance is an ongoing clinical concern. Thus, anticancer activities were next determined towards three ovarian epithelial cancer cell lines, A2780, SKOV3, and SW626 (Table 2). Activity trends between all tested compounds were highly similar, with comparable activities observed towards A2780 (Figure S16) and SW626 and slightly lower activities determined towards SKOV3 cancer cells. A2780 ovarian cancer cells are highly sensitive to cisplatin, whereas ectopic expression of the CA125 tumor antigen C-terminal domain in 
SKOV3 cells decreases their sensitivity to cisplatin [61]. Interestingly, SW626 cancer cells are also thought to be primary ovarian cells, though studies suggested that they might be derived from an ovarian metastasis of a colorectal adenocarcinoma [62].

Table 2. Antiproliferative activities of prepared compounds towards selected ovarian cancer cell lines.

\begin{tabular}{cccccc}
\hline \multirow{2}{*}{ Compound } & \multicolumn{5}{c}{ IC $_{\mathbf{5 0}}(\boldsymbol{\mu M})[\mathbf{a}]$} \\
\cline { 2 - 6 } & $\mathbf{A 2 7 8 0}$ & SKOV3 & SW626 & A2780Cis & A2780ADR \\
\hline $\mathbf{a}$ & $8.6 \pm 0.2$ & $22.5 \pm 0.4$ & $8.4 \pm 0.6$ & n.d. [c] & n.d. [c] \\
\hline $\mathbf{1 a}$ & $1.0 \pm 0.08$ & $6.4 \pm 0.2$ & $3.8 \pm 0.4$ & $1.1 \pm 0.05$ & $1.6 \pm 0.2$ \\
\hline $\mathbf{2 a}$ & $>50[\mathrm{~b}]$ & $>50[\mathrm{~b}]$ & $>50[\mathrm{~b}]$ & n.d. [c] & n.d. [c] \\
\hline $\mathbf{b}$ & $12.4 \pm 0.6$ & $20.3 \pm 0.6$ & $6.4 \pm 0.5$ & n.d. [c] & n.d. [c] \\
\hline $\mathbf{1 b}$ & $2.2 \pm 0.3$ & $5.1 \pm 0.2$ & $2.8 \pm 0.4$ & $2.5 \pm 0.1$ & $2.8 \pm 0.4$ \\
\hline $\mathbf{2 b}$ & $>50[\mathrm{~b}]$ & $>50[\mathrm{~b}]$ & $>50[\mathrm{~b}]$ & n.d. [c] & n.d. [c] \\
\hline Cisplatin & $1.2 \pm 0.3$ & $16.8 \pm 0.8$ & $15.7 \pm 0.8$ & $13.4 \pm 0.3$ & $8.9 \pm 0.5$ \\
\hline
\end{tabular}

[a] Cellular viability determined using the MTT assay after $24 \mathrm{~h}$ drug exposure time at $37^{\circ} \mathrm{C}$ and $72 \mathrm{~h}$ recovery in drug-free media. [b] No activity observed in concentration range investigated. [c] Not determined.

All ligands and chlorido complexes appeared slightly less active towards SKOV3 cells compared to platinum-sensitive A2780 cells. The observed variations in activity could include a contribution from intrinsic cellular differences between A2780 and SKOV3. These cells differ in proliferation rates, receptor expression, and morphology.

Therefore, we also determined antiproliferative activities of the most promising complexes, $\mathbf{1 a}$ and $\mathbf{1 b}$, towards a platinum-resistant variant of A2780 (A2780Cis) to provide direct comparison between platinum-sensitive and platinum-resistant cells (Table 2). Strikingly, the activities of $\mathbf{1 a}$ and $\mathbf{1} \mathbf{b}$ were statistically unchanged between these two cell lines, suggesting that these complexes show promise in the fight against platinum resistance.

In addition to platinum resistance in the clinic, some cancers may acquire resistance to a range of chemotherapeutics, becoming so-called "multi-drug resistant" (MDR) cancers. Thus, the antiproliferative activities of $\mathbf{1} \mathbf{a}$ and $\mathbf{1} \mathbf{b}$ were also determined towards A2780ADR, an Adriamycin-resistant variant of the parent A2780 cell line (Table 2). Both complexes achieved comparably low micromolar $\mathrm{IC}_{50}$ concentrations, between 1.0-1.6 $\mu \mathrm{M}$ for the complex 1a and 2.2-2.8 $\mu \mathrm{M}$ for the complex 1b. Given the likely importance of the $\mathrm{Ru}-\mathrm{Cl}$ bond in the mechanism of action and how orientation of either isomer does not inflict steric interference at the monodentate site, it is perhaps not surprising that, overall, $\mathbf{1 a}$ and its structural isomer $\mathbf{1 b}$ exhibited comparable antiproliferative activities across all human cell lines investigated.

\subsection{Cellular Accumulation of Ruthenium}

Metal complexes may be transported across cell membranes by passive diffusion, transport proteins, or endocytosis [63], where subsequent in-cell activation and anticancer activity may occur $[59,64]$. In addition, efflux mechanisms should also be considered. In combination, both influx and efflux pathways can contribute to drug resistance [63]. For example, cisplatin-resistant A2780C is cells exhibit downregulation of a copper uptake transporter protein (CTR1) and upregulation of efflux transporters multi-drug resistance protein 2 (MRP-2), ATPase copper transporting $\alpha$ (ATP7A), and ATPase copper transporting $\beta[65]$.

Cellular accumulations of ruthenium in cells treated with either active complex 1a or $2 \mathbf{a}$ were determined after $24 \mathrm{~h}$ of incubation with equimolar concentrations $(1.0 \mu \mathrm{M})$ of metal complex. Ruthenium was found to be internalized by A2780 cancer cells treated with either chlorido $\mathbf{1 a}$ or its analogue pta complex $\mathbf{2 a}$, with average accumulations of $1.30 \mathrm{nmol}$ (131.4 ng) Ru/mg protein and $1.02 \mathrm{nmol}$ (103.1 ng) Ru/mg protein, respectively (Table 3). Since A2780 cells were incubated with equimolar concentrations of $\mathbf{1 a}$ and $\mathbf{2} \mathbf{a}$, it is perhaps 
unsurprising that metal accumulations were found to be highly comparable, suggesting that these structurally similar complexes may share a common mechanism of cellular influx. However, what is striking is how similar levels of internalized complex differed in their anticancer activity between $\left(\mathrm{IC}_{50}=1.0 \mu \mathrm{M}\right.$ and $>50 \mu \mathrm{M}$ for $\mathbf{1 a}$ and $\mathbf{2 a}$, respectively). Thus, while the nature of the monodentate site does not appear to influence accumulation, these data provide further evidence for its importance in the overall mechanism of action.

Table 3. Cellular accumulation of ruthenium in A2780 cancer cells treated with $1.0 \mu \mathrm{M}$ of $\mathbf{1 a}$ or $\mathbf{2 a}$ for $24 \mathrm{~h}$ at $37^{\circ} \mathrm{C}$. Ruthenium content in cells was measured using HRCS-AAS.

\begin{tabular}{cc}
\hline Complex & nmol Ru/mg Protein [a] \\
\hline $\mathbf{1 a}$ & $1.30 \pm 0.22$ \\
\hline $\mathbf{2 a}$ & $1.02 \pm 0.15$ \\
\hline Untreated & $0.03 \pm 0.09$ \\
\hline
\end{tabular}

[a] Protein content determined by the Bradford method.

It was previously demonstrated for structurally similar organoruthenium(II) chlorido complexes that cellular uptake does not corelate with the cytotoxicity of the compounds towards A2780 cells [66]. Interestingly, other organoruthenium(II) pta complexes were reported to be inactive on TS/A adenocarcinoma cancer cells despite their cellular uptake [67], as observed with complex $\mathbf{2 a}$.

\subsection{Interactions in Biological Media}

NMR stability studies suggested that ruthenium pta complexes $\mathbf{2} \mathbf{a}-\mathbf{b}$ may undergo greater structural changes in solution (Figures S8-S11) compared to their chlorido analogues 1a-b (Figures S4-S7). To gain further insight into the stability of the compounds in a more complex and biologically relevant environment, the compounds were further studied by UV-visible spectroscopy using (i) phosphate buffer solution PBS, (ii) cell culture medium RPMI-1640, (iii) cell culture medium RPMI-1640 supplemented with $10 \%(v / v)$ fetal calf serum and $1 \%(v / v)$ penicillin/streptomycin antibiotics, and (iv) human blood plasma by UV-Vis spectrometry. As similarly observed in preliminary NMR stability studies, chlorido complexes 1a and $\mathbf{1 b}$ (Figure 3A and Figure S12A, respectively) remained stable in all four media. While pta complexes $\mathbf{2} \mathbf{a}$ and $\mathbf{2} \mathbf{b}$ retained modest stability in phosphate-buffered saline, as observed in NMR studies, spectral changes were observed in all other media (Figure 3B and Figure S12B, respectively). The observed UV-Vis spectral changes of the pta complexes could relate to a commonality between RPMI-1640 culture medium (in the fetal calf serum supplemented and non-supplemented samples) and human blood plasma. Hence, addition of fetal calf serum to the supplemented media sample was not essential to causing this change. Both RPMI-1640 and human plasma contain significant levels of nucleophilic components (e.g., $1 \mathrm{mM}$ reduced glutathione in RPMI-1640, with similar levels measured in human plasma [68]) which may interfere with coordinated pta. More generally, UV-Vis studies together with NMR stability experiments point to more possible structural changes of investigated pta than chlorido complexes that might contribute to the lack of observed in vitro activity of $\mathbf{2} \mathbf{a}$ and $\mathbf{2} \mathbf{b}$ in the presence of cell culture medium. 


\section{A) Complex 1a}
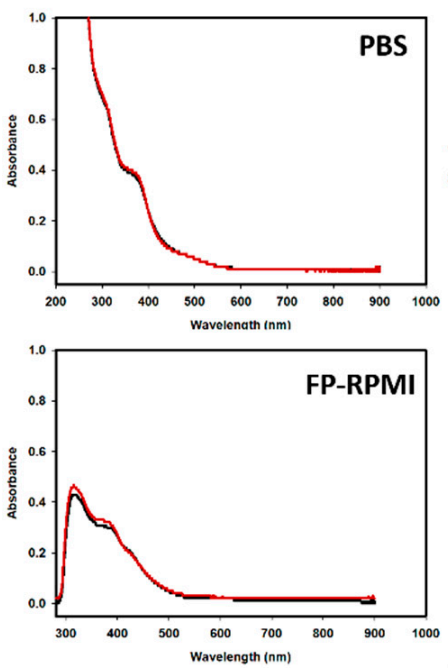
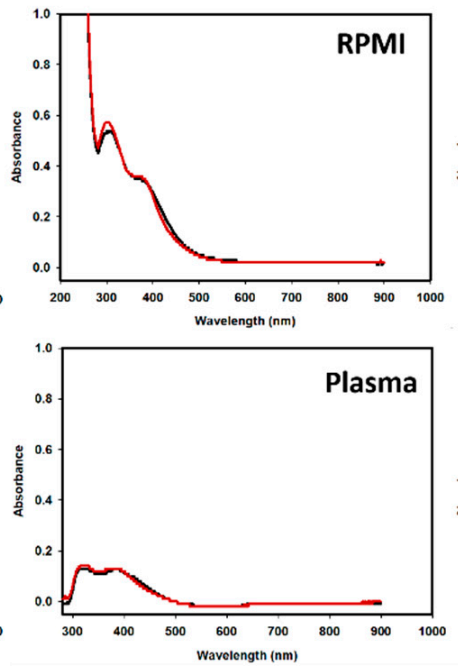

B) Complex 2a
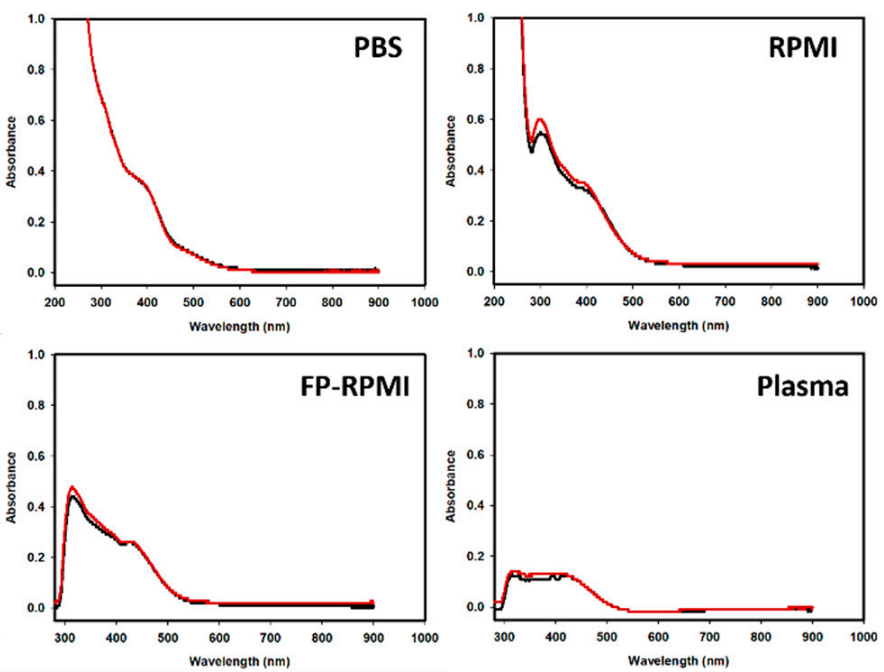

Figure 3. UV-Vis spectra of (A) organoruthenium(II) chlorido 1a and (B) pta complex 2a in PBS, RPMI-1640, FP-RPMI-1640, and human blood plasma recorded immediately after the preparation (black) and after $24 \mathrm{~h}$ (red).

\subsection{Explorations of the Mechanism of Action}

We previously reported similar pyrithione ligands which became effective inhibitors of thioredoxin reductase (TrxR) when associated with the architecture of a metal complex [41]. This enzyme (alongside thioredoxin and NADPH) makes up the thioredoxin system, which is involved in processes such as control of the intracellular redox environment, cellular growth, and the regulation of apoptosis [69]. As such, the thioredoxin system is an interesting target in the development of anticancer drugs [70]. In fact, overexpressed thioredoxin in some cancer cells was implicated as a contributor to platinum resistance due to its involvement in the regulation of apoptosis [71]. Similarly, inhibition of thioredoxin reductase by the gold(I) drug auranofin was proposed to enhance cell death in cisplatinresistant human ovarian cancer cells [72].

As complex 1a retained activity towards both platinum sensitive (A2780) and resistant (A2780Cis) cancer cells, interactions between complex 1a and thioredoxin reductase were investigated. During the preliminary assay, a concentration of $10 \mu \mathrm{M}$ complex 1a caused $94 \%$ inhibition of TrxR, with an $\mathrm{IC}_{50}$ of $4.1 \pm 0.16 \mu \mathrm{M}$ determined in dose-response experiments. We also observed that ligand a (from which complex 1a was derived) did not inhibit TrxR. Considering that the determined inhibitory concentration of $\operatorname{Tr} x \mathrm{R}(4.1 \mu \mathrm{M})$ was also comparable with the determined anticancer growth inhibition concentration $(1.0 \mu \mathrm{M}), \operatorname{Tr} x \mathrm{R}$ is a possible subcellular target of $\mathbf{1 a}$ and may contribute to the in vitro mechanism of action. Involvement of TrxR in the MoA of a multi-targeting metal complex presents a possible explanation for the ability of 1a to overcome platinum resistance in A2780 cancer cells.

Since complex 1a appears to inhibit thioredoxin reductase activity in model experiments, and TrxR is linked to cellular redox regulation, we explored evidence for this observation in vitro by fluorescence microscopy. While low to moderate concentrations of reactive oxygen species (ROS) are reported to be important for normal functioning of some physiological processes, elevated ROS species can damage proteins, nucleic acids, lipids, and membranes, which may activate either non-physiological (necrotic) or regulated (apoptotic) cell death pathways [73,74]. Many metal complexes are known to cause enhanced ROS formation [75-78]. We therefore evaluated the induction of reactive oxygen species (ROS) in A2780 cells by complex 1a. However, our results showed that the compound 1a only induced a small increase in intracellular ROS levels (fluorescence intensity ca. 700 fluorescence units) compared to the untreated control (ca. 650 fluorescence units; Figure 4), with measured ROS levels in treated cells only slightly above basal signaling levels in untreated cells. In contrast, positive controls hydrogen peroxide and Luperox 
displayed significantly elevated fluorescence relative to the untreated control (ca. 950 and 1050 fluorescence units, respectively).
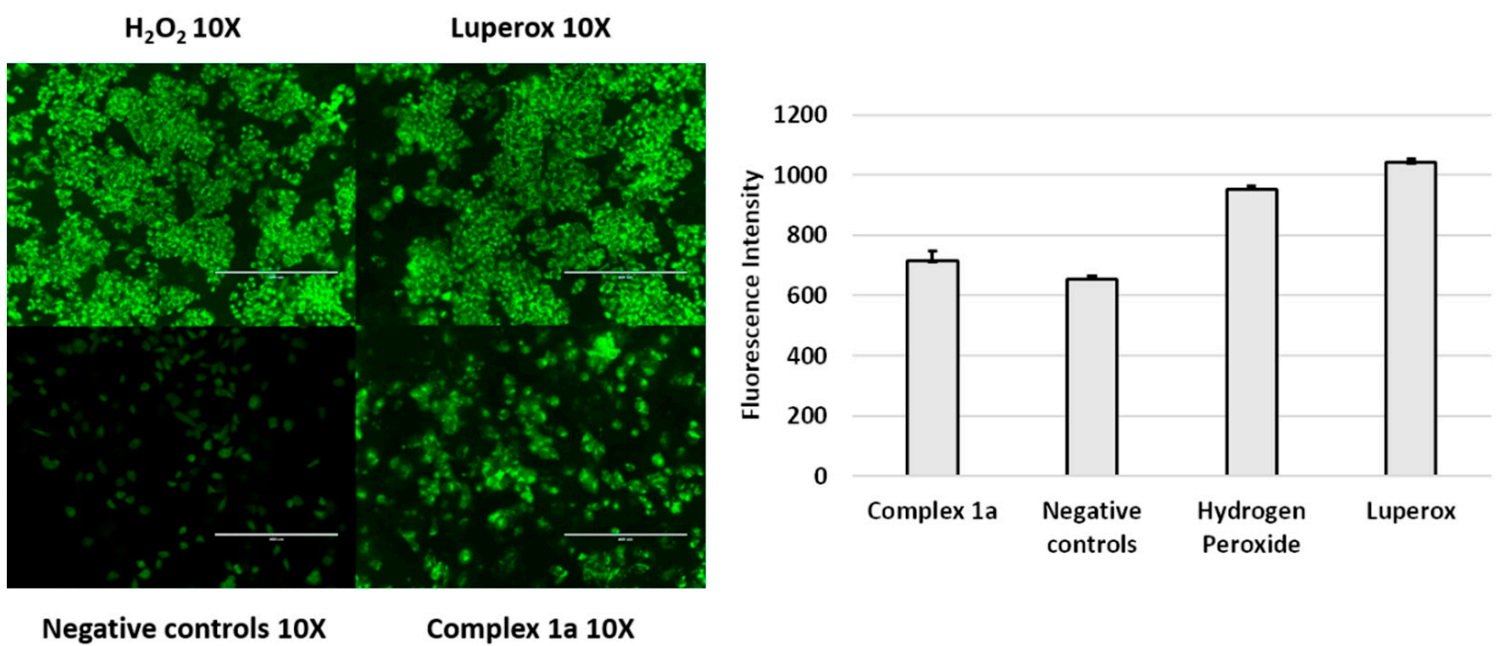

Figure 4. A2780 cancer cells stained with DCFDA. Samples include no treatment (negative control), 24 h exposure at $37^{\circ} \mathrm{C}$ to complex $1 \mathrm{a}(1.0 \mu \mathrm{M})$, as well as $1 \mathrm{~h}$ exposure to hydrogen peroxide $\left(\mathrm{H}_{2} \mathrm{O}_{2}\right)$ and $1 \mathrm{~h}$ exposure to Luperox. Fluorescence measured using an EVOS fluorescence microscope $\left(\lambda_{\mathrm{Ex}}=485 \mathrm{~nm}, \lambda_{\mathrm{Em}}=530 \mathrm{~nm}\right)$.

Reactive oxygen species are the byproduct of oxidative phosphorylation, and enhanced ROS concentrations are often correlated with mitochondrial dysfunction [79]. Since levels of ROS were relatively unchanged by treatment of A2780 cells with 1a, mitochondrial function in treated cells was also evaluated to provide further evidence that ROS are unlikely to play a major role in the in-cell mechanism of complex 1a (Figure 5). In both untreated controls and treated cells, blue fluorescence (DAPI) suggested that cells did not exhibit significant nuclear morphology changes, consistent with previous experiments. Similarly, green fluorescence (Rhodamine-123) showed that mitochondrial function was unaffected by treatment with 1a compared to the untreated control (Figure S17) under the conditions investigated.

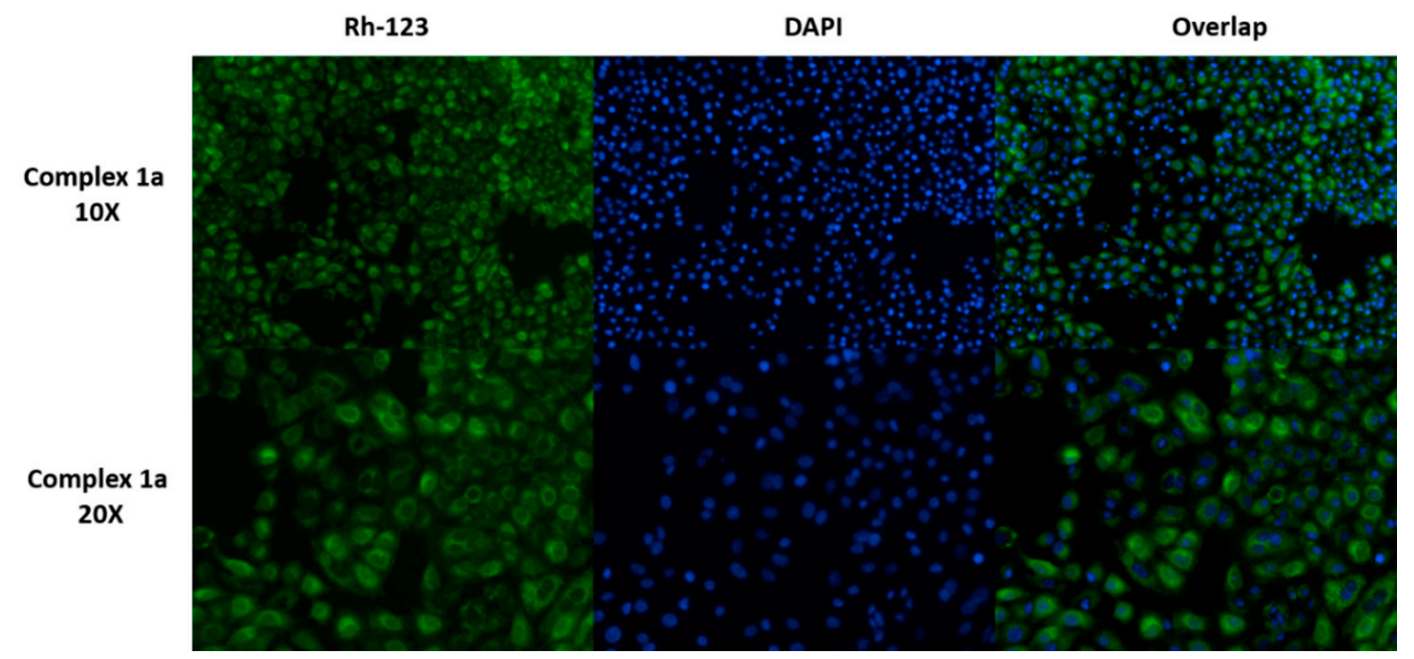

Figure 5. A2780 cancer cells stained with Rhodamine-123 (green) or DAPI (blue) after incubation of cells with complex 1a $(1.0 \mu \mathrm{M})$ for $24 \mathrm{~h}$ at $37^{\circ} \mathrm{C}$. Fluorescence measured using a fluorescence microscope using Rh-123 $\left(\lambda_{\mathrm{Ex}}=511 \mathrm{~nm}\right.$; $\left.\lambda_{\mathrm{Em}}=534 \mathrm{~nm}\right)$ and DAPI $\left(\lambda_{\mathrm{Ex}}=340 \mathrm{~nm} ; \lambda_{\mathrm{Em}}=488 \mathrm{~nm}\right)$. 
Further evidence of the lack of redox involvement of complex 1a was provided by cyclic voltammetry studies, including ligand $\mathbf{a}$, and analogous pta complex $2 \mathbf{a}$. While all three compounds are redox active between $-2.0 \mathrm{~V}$ to $+2.0 \mathrm{~V}$ (Figure $6 \mathrm{~A}$ ), only uncoordinated ligand a exhibited redox activity between the biologically-relevant range of $-0.8 \mathrm{~V}$ and $+0.8 \mathrm{~V}$ (Figure 6B). Thus, while ruthenium pyrithione complexes $\mathbf{1 a}$ and $\mathbf{2 a}$ are unlikely to be involved in cellular redox processes, it is possible that cellular degradation pathways may mediate release of free ligand $\mathbf{a}$, which may account for the observations of slightly elevated ROS levels compared to the untreated control (Figure 4). Such degradation pathways were previously identified for structurally similar osmium-arene complexes utilizing combination studies of ICP-MS and X-ray fluorescence microscopy, involving endosomal degradation and glutathione [80].

A

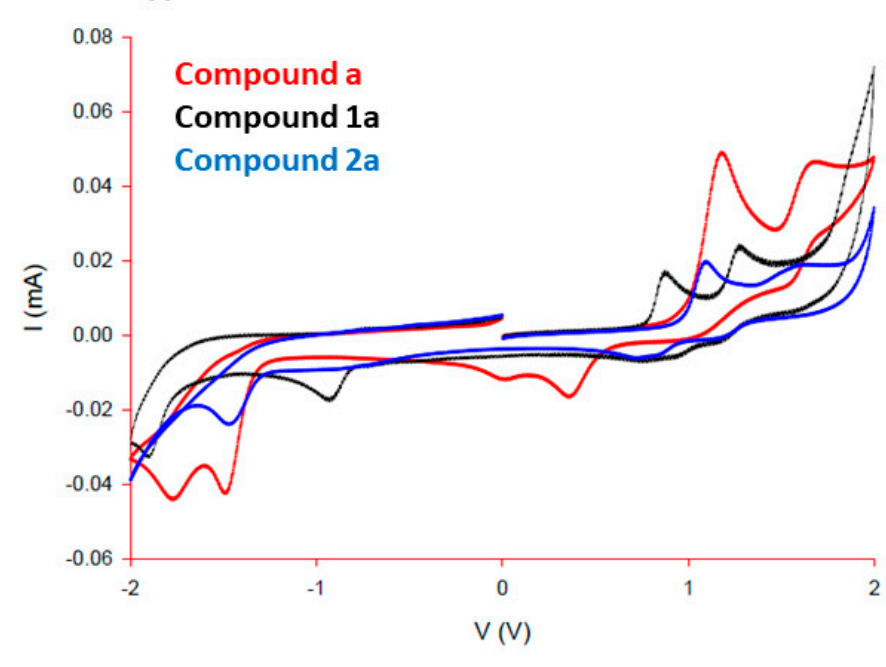

B

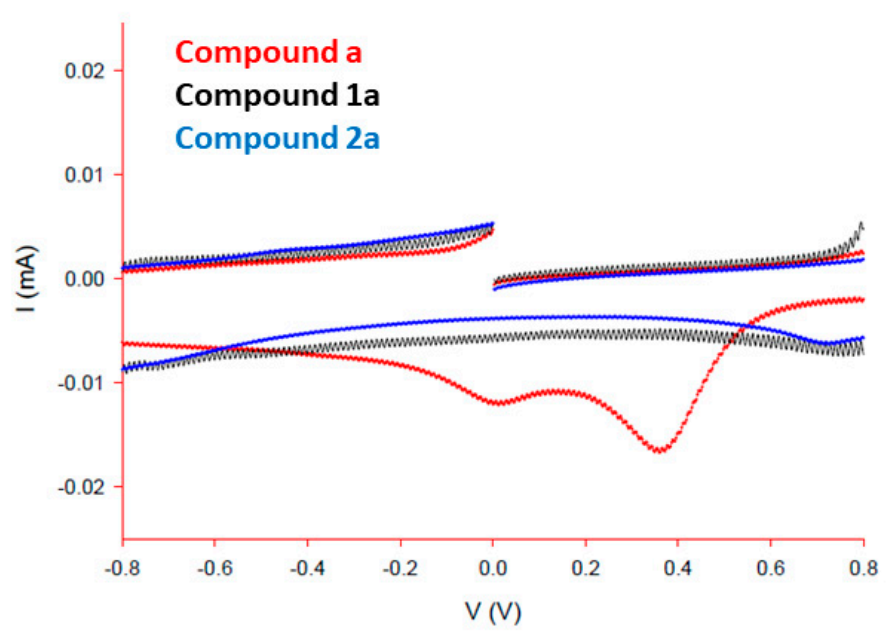

Figure 6. Cyclic voltammograms for the compounds a, 1a and 2a: (A) full scan and (B) biologically relevant scan region.

Upon excluding ROS and mitochondrial targeting from the likely major mechanism of complex 1a in cells, a cell cycle analysis of A2780 cancer cells treated with compound 1a was determined (Table 4). In platinum-sensitive cells, platinum-based therapies exhibit $S+$ $\mathrm{G}_{2} / \mathrm{M}$-phase cell cycle arrest as a result of binding DNA, thereby preventing DNA synthesis. This results in the activation of p53/p21 pathways, leading to cellular apoptosis [81]. However, in platinum-resistant cells, DNA repair mechanisms such as the nucleotide excision repair systems (NER) can repair platinated DNA adducts, preventing $S+G_{2} / M$ cell cycle arrest and promoting platinum resistance [82]. In order to overcome platinum resistance, multi-targeted compounds must identify unique subcellular targets that are not common to platinum drugs. After incubation of A2780 cancer cells with complex 1a, the cell cycle $G_{1}$ population was significantly increased relative to the untreated control $(72.5 \%$ compared to $62.5 \%$, respectively). As such, it appears that the mechanism of action of $\mathbf{1 a}$ is not common to platinum-based compounds. It is well established that metal complexes often exhibit multi-targeting mechanisms [24], and we suggest that the compound 1a is likely to interact with various sub-cellular components other than DNA.

Table 4. Cell cycle analysis of A2780 cancer cells treated with complex $1 \mathrm{a}(1.0 \mu \mathrm{M})$ for $24 \mathrm{~h}$ at $37^{\circ} \mathrm{C}$ and analyzed by flow cytometry after fixation in ethanol and staining with propidium iodide.

\begin{tabular}{cccc}
\hline Complex & G1 & G2/M & S \\
\hline 1a & $72.5 \pm 0.5$ & $12.6 \pm 0.7$ & $14.9 \pm 0.6$ \\
\hline Untreated & $62.3 \pm 0.3$ & $17.8 \pm 0.4$ & $19.9 \pm 0.8$ \\
\hline
\end{tabular}


On detecting significant $\mathrm{G}_{1}$ arrest caused by complex 1a, the induction of apoptosis (programmed cell death) in A2780 cancer cells was investigated to determine whether the mechanism of 1a was cytotoxic or cytostatic (Table 5). Cells were stained with propidium iodide (PI) and Annexin-V (FITC conjugate; ANN) to identify loss of membrane integrity (PI able to enter cells and bind to DNA) and the translocation of phosphatidylserine to the outer membrane, a trait commonly associated with late-stage apoptosis. A2780 cells treated with complex 1a only showed partial evidence for apoptotic cell death $(8.4 \%$ of cell population), with a greater cell population determined as non-viable cells $(11.2 \%$ of cell population), indicative of a major non-apoptotic pathway in the mechanism of action. Apoptotic cell death pathway is frequently identified with platinum agents, and its activation is mediated by a variety of mechanisms. For example, while platinumassociated apoptosis is typically dependent on the activation of tumor suppressor protein p53, ruthenium complexes were reported to induce ERK1/2-mediated apoptosis via a p53-indpendent pathway [83]. While it appears that this new class of ruthenium complexes does cause slight apoptosis, this level is unlikely to contribute to the main mechanism of action of such complexes towards A2780 cancer cells.

Table 5. Gated populations for flow cytometric analysis of cellular apoptosis in A2780 cancer cells treated with complex $1 \mathrm{a}(1.0 \mu \mathrm{M})$ for $24 \mathrm{~h}$ at $37^{\circ} \mathrm{C}$. Cells stained with propidium iodide (PI) and Annexin-V-FITC (ANN) without fixation.

\begin{tabular}{ccccc}
\hline Complex & PI-/ANN- & PI+/ANN- & PI-/ANN+ & PI+/ANN+ \\
\hline 1a & $76.5 \pm 0.9^{* *}$ & $11.2 \pm 0.8^{* *}$ & $4.1 \pm 0.4^{* *}$ & $8.4 \pm 0.7^{* *}$ \\
\hline Untreated & $95.6 \pm 0.7$ & $2 \pm 1$ & $2 \pm 1$ & $0.3 \pm 0.2$ \\
\hline${ }^{* *} p$-value $<0.01$. & & & &
\end{tabular}

Owing to the large population of non-viable cells after treatment with 1a, the membrane integrity of exposed cells was evaluated. Cells exhibiting compromised membranes in the absence of apoptotic cell death may indicate the involvement of a necrotic cell death pathway. Interestingly, while cells did not exhibit significant nuclear morphology changes (viable blue DAPI florescence), complex 1a appeared to disrupt the cell membrane, allowing propidium iodide (PI) to enter cells, causing red florescence upon binding cellular DNA (Figure 7). Further, this finding is consistent with the observation of a greater population of cells in the PI+ quadrant during the investigation of apoptosis (Table 5).

The influence of complex 1a on the migration of A2780 cancer cells was next investigated as part of a wound-healing assay (Figure 8). A wound was created in a monolayer of A2780 cells using the pipette tip $(1282 \pm 59 \mu \mathrm{m})$. Cells treated with complex 1a were observed and compared to the untreated (negative) control to determine whether the presence of the ruthenium complex would influence wound healing or cell motility. After $24 \mathrm{~h}$ exposure to $1 \mathrm{a}$, the wound healing was significantly hindered $(p<0.05)$ compared to the untreated cell population, exhibiting a wound width of $1035 \pm 89 \mu \mathrm{m}$ (19\% reduction) compared to $319 \pm 35 \mu \mathrm{m}$ (75\% reduction), respectively. Cells treated with 1a showed a reduction in motility towards wound healing, which is consistent with previously observed $\mathrm{G}_{1}$ arrest. Since such cell cycle arrest extends the growth phase and delays DNA replication and subsequent cell division, these findings suggest that the mechanism of action appears to be cytostatic, as opposed to cytotoxic. In addition, cell colonies treated with complex 1a for $24 \mathrm{~h}$ were found to be significantly smaller and fewer in number $(24 \pm 5$ colonies $)$ compared to untreated colonies ( $45 \pm 3$ colonies) after 7 days growth $(p<0.01)$. This result is again consistent with the observation of $\mathrm{G}_{1}$ cell cycle arrest and a cytostatic (rather than cytotoxic) mechanism of action. 


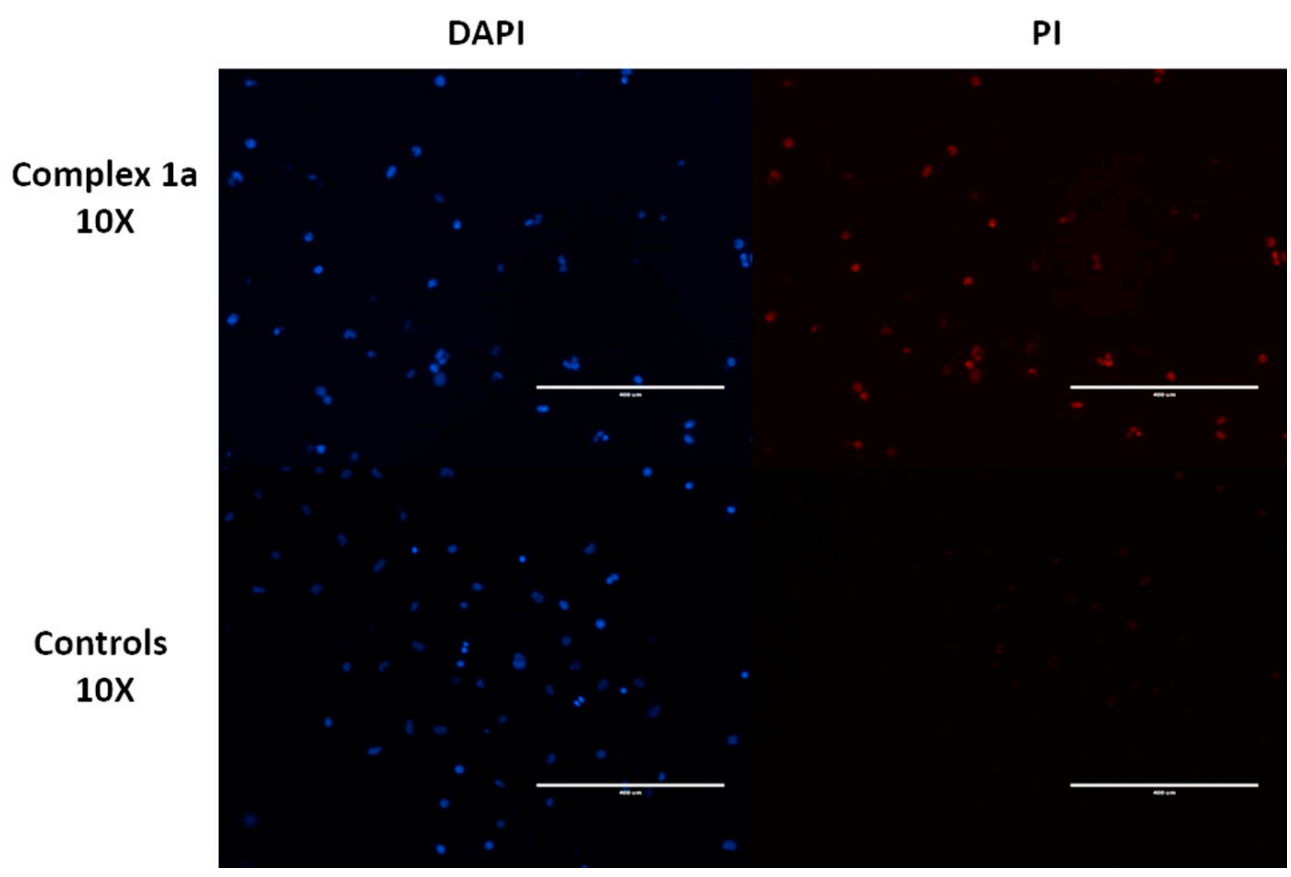

Figure 7. Evaluation of membrane integrity of A2780 cancer cells treated with complex 1a $(1.0 \mu \mathrm{M})$ for $24 \mathrm{~h}$ at $37^{\circ} \mathrm{C}$ compared to the untreated control. Unfixed cells were stained using DAPI (blue) or propidium iodide (red), showing clear disruption of membrane integrity in the presence of complex 1a, thus allowing PI to enter cells and fluoresce upon binding DNA.

\section{Controls 10X \\ Complex 1a 10X}

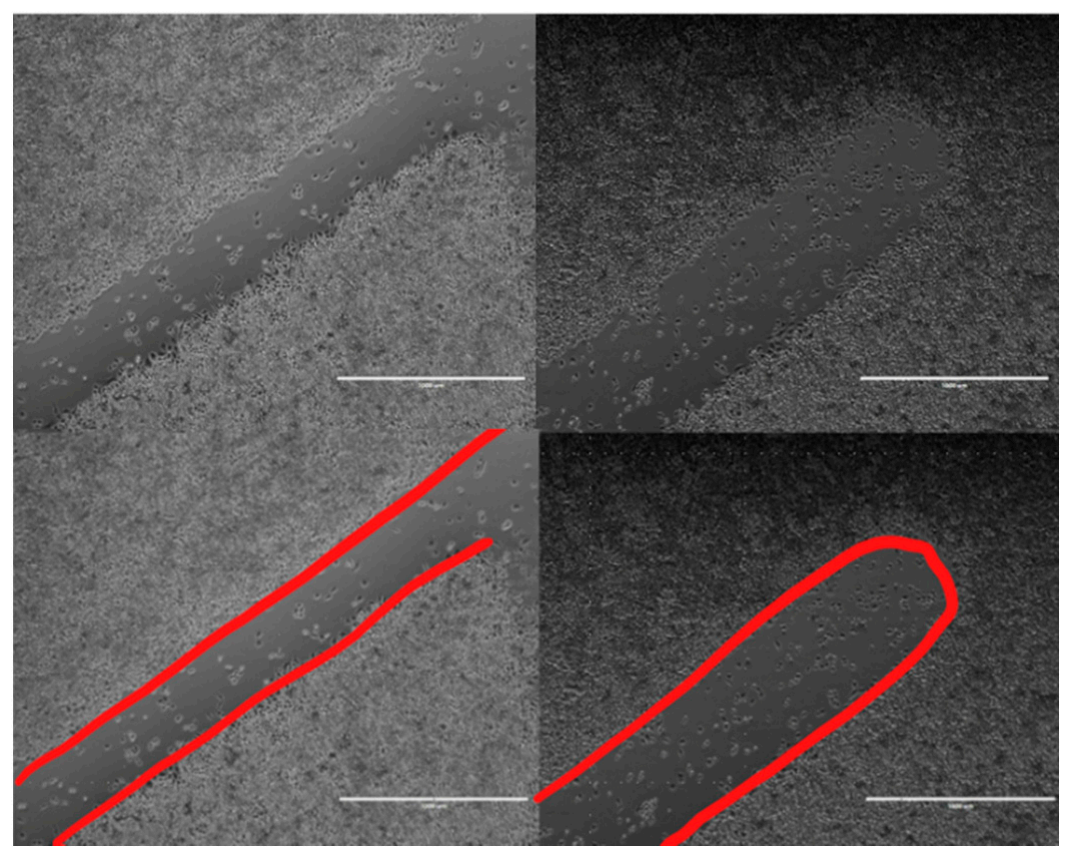

Figure 8. Wound healing assay for A2780 cancer cells after wounding using a pipette tip (average day 0 wound size $1282 \pm 59 \mu \mathrm{m}$ ) after $24 \mathrm{~h}$ incubation at $37^{\circ} \mathrm{C}$ in the presence or the absence (untreated control) of complex 1a $(1.0 \mu \mathrm{M})$. Complex 1a significantly reduces cell motility towards the wound $(p<0.05)$.

\section{Conclusions}

A new series of organoruthenium(II) pyrithione complexes were described, which show promising potency towards ovarian cancer cells. The nature of the monodentate 
site was confirmed to be crucial in the activation and/or the mechanism of action of these complexes, as substitution of the chlorido moiety for pta rendered the complexes inert under the test conditions of our experiments. This work suggests that the mode of action of $1 \mathbf{a}$ is cytostatic in nature, involving $\mathrm{G}_{1}$ cell cycle arrest, the absence of ROS generation of mitochondrial dysfunction, reduced cell motility, reduced cell colony size, and limited induction of apoptosis. Similarly, cells treated with 1a were found to exhibit damaged cell membranes, in agreement with the increased non-viable cell population determined by flow cytometry as part of apoptosis experiments. Importantly, the mechanism of action appears to differ from the well-established DNA binding mechanism of action of platinum anti-cancer agents, and our findings offer an explanation as to how complex 1a appears to overcome platinum resistance in ovarian cancer cells. In addition, complex 1a also inhibits TrxR, enzyme involved in cancer development. Our findings highlight how a multi-targeting mechanism of action offered by such metal complexes can contribute to future development of cancer therapies to combat drug resistance.

Supplementary Materials: The following are available online at https:/ /www.mdpi.com/article/ 10.3390/cancers13102493/s1, Figure S1: General scheme of A) prepared ligands $\mathbf{a}-\mathbf{b}$ and B) their organoruthenium(II) chlorido $\mathbf{1} \mathbf{a}-\mathbf{b}$ and pta $\mathbf{2 a}-\mathbf{b}$ complexes. Figure S2: Photos of single crystals for ligand $\mathbf{a}$ (left) and pta complex $\mathbf{2 b}$ (right). Figure S3: Packing of molecules of ligand $\mathbf{a}$. Figure S4: ${ }^{1} \mathrm{H}$ NMR spectra of organoruthenium(II) chlorido complex 1a in $5 \%\left(\mathrm{CD}_{3}\right)_{2} \mathrm{SO} / \mathrm{D}_{2} \mathrm{O}$ containing $140 \mathrm{mM} \mathrm{NaCl}$ at the chosen timepoints. Figure S5: ${ }^{1} \mathrm{H}$ NMR spectra of organoruthenium(II) chlorido complex $1 \mathrm{a}$ in $5 \%\left(\mathrm{CD}_{3}\right)_{2} \mathrm{SO} / \mathrm{D}_{2} \mathrm{O}$ without $\mathrm{NaCl}$ at the chosen timepoints. Figure S6: ${ }^{1} \mathrm{H} \mathrm{NMR}$ spectra of organoruthenium(II) chlorido complex $1 \mathbf{b}$ in $5 \%\left(\mathrm{CD}_{3}\right)_{2} \mathrm{SO} / \mathrm{D}_{2} \mathrm{O}$ containing $140 \mathrm{mM} \mathrm{NaCl}$ at the chosen timepoints. Figure S7: ${ }^{1} \mathrm{H}$ NMR spectra of organoruthenium(II) chlorido complex $\mathbf{1 b}$ in $5 \%\left(\mathrm{CD}_{3}\right)_{2} \mathrm{SO} / \mathrm{D}_{2} \mathrm{O}$ without $\mathrm{NaCl}$ at the chosen timepoints. Figure $58:{ }^{1} \mathrm{H}$ NMR spectra of organoruthenium(II) pta complex 2a in $5 \%\left(\mathrm{CD}_{3}\right)_{2} \mathrm{SO} / \mathrm{D}_{2} \mathrm{O}$ containing $140 \mathrm{mM} \mathrm{NaCl}$ at the chosen timepoints. Figure S9: ${ }^{1} \mathrm{H}$ NMR spectra of organoruthenium(II) pta complex $2 \mathrm{a}$ in $5 \%\left(\mathrm{CD}_{3}\right)_{2} \mathrm{SO} / \mathrm{D}_{2} \mathrm{O}$ without $\mathrm{NaCl}$ at the chosen timepoints. Figure S10: $1 \mathrm{H}$ NMR spectra of organoruthenium(II) pta complex $\mathbf{2 b}$ in $5 \%\left(\mathrm{CD}_{3}\right)_{2} \mathrm{SO} / \mathrm{D}_{2} \mathrm{O}$ containing $140 \mathrm{mM} \mathrm{NaCl}$ at the chosen timepoints. Figure S11: ${ }^{1} \mathrm{H}$ NMR spectra of organoruthenium(II) pta complex $2 \mathbf{b}$ in $5 \%\left(\mathrm{CD}_{3}\right)_{2} \mathrm{SO} / \mathrm{D}_{2} \mathrm{O}$ without $\mathrm{NaCl}$ at the chosen timepoints. Figure S12: UV-Vis spectra of A) organoruthenium(II) chlorido $\mathbf{1 b}$ and B) pta complex 2b in PBS, RPMI-1640, FP-RPMI-1640, and human blood plasma recorded immediately after the preparation (black curve) and after $24 \mathrm{~h}$ (red curve). Figure S13: ${ }^{1} \mathrm{H}$ NMR spectrum of $2 \mathrm{a}$. Figure S14: ${ }^{1} \mathrm{H}$ NMR spectrum of $\mathbf{2 b}$. Figure S15: Antiproliferative activities of the ruthenium dimer precursor towards A2780 ovarian cancer cells and A549 lung cancer cells. Figure S16: Antiproliferative activities of the prepared compounds towards A2780 ovarian cancer cells. Figure S17: Negative controls for A2780 cancer cells stained with Rhodamine-123 (green) or DAPI (blue). Table S1: Crystallographic data for ligand $\mathbf{a}$ and complex $\mathbf{2} \mathbf{b}$.

Author Contributions: Conceptualization, I.O., I.R.-C. and I.T.; investigation, J.K. (Jerneja Kladnik), J.K. (Jakob Kljun), H.B., P.L., F.G.E., A.M.J., I.R.-C.; writing—original draft preparation, J.K. (Jerneja Kladnik), J.P.C.C., I.R.-C.; writing-review and editing, J.K. (Jakob Kljun), H.B., A.M.J., I.O., I.T.; visualization, J.K. (Jerneja Kladnik), I.R.-C.; supervision, I.T.; funding acquisition, I.O., I.R.-C., I.T. All authors have read and agreed to the published version of the manuscript.

Funding: This research was funded by Junior Researcher Grant for J.K. (Jerneja Kladnik), the program Grant P1-0175, and bilateral project grant number I-DE/17-19-3 of the Slovenian Research Agency (ARRS).

Institutional Review Board Statement: Not applicable.

Informed Consent Statement: Not applicable.

Data Availability Statement: Data is contained within the article or supplementary material.

Acknowledgments: The authors thank the EN $\rightarrow$ FIST Centre of Excellence, Dunajska 156, SI-1000 Ljubljana, Slovenia, for the use of a SuperNova diffractometer. This article is based upon work from COST Action STRATAGEM, CA17104, supported by COST (European Cooperation in Science and Technology), www.cost.eu (accessed on 16 May 2021). 
Conflicts of Interest: The authors declare no conflict of interest.

\section{References}

1. Bray, F.; Ferlay, J.; Soerjomataram, I.; Siegel, R.L.; Torre, L.A.; Jemal, A. Global cancer statistics 2018: GLOBOCAN estimates of incidence and mortality worldwide for 36 cancers in 185 countries. CA Cancer J. Clin. 2018, 68, 394-424. [CrossRef] [PubMed]

2. Torre, L.A.; Trabert, B.; DeSantis, C.E.; Miller, K.D.; Samimi, G.; Runowicz, C.D.; Gaudet, M.M.; Jemal, A.; Siegel, R.L. Ovarian Cancer Statistics, 2018. CA Cancer J. Clin. 2018, 68, 284-296. [CrossRef]

3. Ferlay, J.; Colombet, M.; Soerjomataram, I.; Mathers, C.; Parkin, D.M.; Piñeros, M.; Znaor, A.; Bray, F. Estimating the global cancer incidence and mortality in 2018: GLOBOCAN sources and methods. Int. J. Cancer 2019, 144, 1941-1953. [CrossRef] [PubMed]

4. Zhang, Y.; Luo, G.; Li, M.; Guo, P.; Xiao, Y.; Ji, H.; Hao, Y. Global patterns and trends in ovarian cancer incidence: Age, period and birth cohort analysis. BMC Cancer 2019, 19, 984. [CrossRef]

5. Momenimovahed, Z.; Tiznobaik, A.; Taheri, S.; Salehiniya, H. Ovarian cancer in the world: Epidemiology and risk factors. Int. J. Womens Health 2019, 11, 287-299. [CrossRef] [PubMed]

6. Flaum, N.; Crosbie, E.J.; Edmondson, R.J.; Smith, M.J.; Evans, D.G. Epithelial ovarian cancer risk: A review of the current genetic landscape. Clin. Genet. 2020, 97, 54-63. [CrossRef] [PubMed]

7. Matulonis, U.A.; Sood, A.K.; Fallowfield, L.; Howitt, B.E.; Sehouli, J.; Karlan, B.Y. Ovarian cancer. Nat. Rev. Dis. Primers 2016, 2, 16061. [CrossRef]

8. McLemore, M.R.; Miaskowski, C.; Aouizerat, B.E.; Chen, L.M.; Dodd, M.J. Epidemiological and genetic factors associated with ovarian cancer. Cancer Nurs. 2009, 32, 281-288. [CrossRef]

9. Cortez, A.J.; Tudrej, P.; Kujawa, K.A.; Lisowska, K.M. Advances in ovarian cancer therapy. Cancer Chemother. Pharmacol. 2018, 81, 17-38. [CrossRef] [PubMed]

10. Ren, F.; Shen, J.; Shi, H.; Hornicek, F.J.; Kan, Q.; Duan, Z. Novel mechanisms and approaches to overcome multidrug resistance in the treatment of ovarian cancer. Biochim. Biophys. Acta Rev. Cancer 2016, 1866, 266-275. [CrossRef]

11. Bukowski, K.; Kciuk, M.; Kontek, R. Mechanisms of multidrug resistance in cancer chemotherapy. Int. J. Mol. Sci. 2020, 21, 3233. [CrossRef] [PubMed]

12. Gothe, Y.; Marzo, T.; Messori, L.; Metzler-Nolte, N. Iridium(I) compounds as prospective anticancer agents: Solution chemistry, antiproliferative profiles and protein interactions for a series of iridium(I) N-heterocyclic carbene complexes. Chem. Eur. J. 2016, 22, 12487-12494. [CrossRef] [PubMed]

13. Coverdale, J.P.C.; Romero-Canelón, I.; Sanchez-Cano, C.; Clarkson, G.J.; Habtemariam, A.; Wills, M.; Sadler, P.J. Asymmetric transfer hydrogenation by synthetic catalysts in cancer cells. Nat. Chem. 2018, 10, 347-354. [CrossRef] [PubMed]

14. Hanif, M.; Babak, M.V.; Hartinger, C.G. Development of anticancer agents: Wizardry with osmium. Drug Discov. Today 2014, 19, 1640-1648. [CrossRef] [PubMed]

15. Zhang, P.; Huang, H. Future potential of osmium complexes as anticancer drug candidates, photosensitizers and organelletargeted probes. Dalton Trans. 2018, 47, 14841-14854. [CrossRef] [PubMed]

16. Almodares, Z.; Lucas, S.J.; Crossley, B.D.; Basri, A.M.; Pask, C.M.; Hebden, A.J.; Phillips, R.M.; McGowan, P.C. Rhodium, iridium, and ruthenium half-sandwich picolinamide complexes as anticancer agents. Inorg. Chem. 2014, 53, 727-736. [CrossRef]

17. Threatt, S.D.; Synold, T.W.; Wu, J.; Barton, J.K. In vivo anticancer activity of a rhodium metalloinsertor in the HCT116 tumor model. Proc. Natl. Acad. Sci. USA 2020, 117, 17535-17542. [CrossRef]

18. Hartinger, C.G.; Jakupec, M.A.; Zorbas-Seifried, S.; Groessl, M.; Egger, A.; Berger, W.; Zorbas, H.; Dyson, P.J.; Keppler, B.K. KP1019, a new redox-active anticancer agent-Preclinical development and results of a clinical phase I study in tumor patients. Chem. Biodivers. 2008, 5, 2140-2155. [CrossRef] [PubMed]

19. Leijen, S.; Burgers, S.A.; Baas, P.; Pluim, D.; Tibben, M.; van Werkhoven, E.; Alessio, E.; Sava, G.; Beijnen, J.H.; Schellens, J.H.M. Phase I/II study with ruthenium compound NAMI-A and gemcitabine in patients with non-small cell lung cancer after first line therapy. Investig. New Drugs 2015, 33, 201-214. [CrossRef] [PubMed]

20. Alessio, E.; Messori, L. NAMI-A and KP1019/1339, two iconic ruthenium anticancer drug candidates face-to-face: A case story in medicinal inorganic chemistry. Molecules 2019, 24, 1995. [CrossRef]

21. Coverdale, J.P.C.; Laroiya-McCarron, T.; Romero-Canelón, I. Designing ruthenium anticancer drugs: What have we learnt from the key drug candidates? Inorganics 2019, 7, 31. [CrossRef]

22. Soldevila-Barreda, J.J.; Romero-Canelón, I.; Habtemariam, A.; Sadler, P.J. Transfer hydrogenation catalysis in cells as a new approach to anticancer drug design. Nat. Commun. 2015, 6, 6582. [CrossRef] [PubMed]

23. Wernitznig, D.; Kiakos, K.; Del Favero, G.; Harrer, N.; Machat, H.; Osswald, A.; Jakupec, M.A.; Wernitznig, A.; Sommergruber, W.; Keppler, B.K. First-in-class ruthenium anticancer drug (KP1339/IT-139) induces an immunogenic cell death signature in colorectal spheroids in vitro. Metallomics 2019, 11, 1044-1048. [CrossRef]

24. Zeng, L.; Gupta, P.; Chen, Y.; Wang, E.; Ji, L.; Chao, H.; Chen, Z.S. The development of anticancer ruthenium(II) complexes: From single molecule compounds to nanomaterials. Chem. Soc. Rev. 2017, 46, 5771-5804. [CrossRef] [PubMed]

25. Flocke, L.S.; Trondl, R.; Jakupec, M.A.; Keppler, B.K. Molecular mode of action of NKP-1339—A clinically investigated rutheniumbased drug_-involves ER- and ROS-related effects in colon carcinoma cell lines. Investig. New Drugs 2016, 34, 261-268. [CrossRef] 
26. Bergamo, A.; Masi, A.; Peacock, A.F.A.; Habtemariam, A.; Sadler, P.J.; Sava, G. In vivo tumour and metastasis reduction and in vitro effects on invasion assays of the ruthenium RM175 and osmium AFAP51 organometallics in the mammary cancer model. J. Inorg. Biochem. 2010, 104, 79-86. [CrossRef]

27. Frühauf, S.; Zeller, W.J. In vitro evaluation of platinum, titanium and ruthenium metal complexes in cisplatin-sensitive and -resistant rat ovarian tumors. Cancer Chemother. Pharmacol. 1991, 27, 301-307. [CrossRef] [PubMed]

28. Morris, R.E.; Aird, R.E.; del Socorro Murdoch, P.; Chen, H.; Cummings, J.; Hughes, N.D.; Parsons, S.; Parkin, A.; Boyd, G.; Jodrell, D.I.; et al. Inhibition of cancer cell growth by ruthenium(II) arene complexes. J. Med. Chem. 2001, 44, 3616-3621. [CrossRef]

29. Aird, R.E.; Cummings, J.; Ritchie, A.A.; Muir, M.; Morris, R.E.; Chen, H.; Sadler, P.J.; Jodrell, D.I. In vitro and in vivo activity and cross resistance profiles of novel ruthenium (II) organometallic arene complexes in human ovarian cancer. Br. J. Cancer 2002, 86, 1652-1657. [CrossRef]

30. Grozav, A.; Balacescu, O.; Balacescu, L.; Cheminel, T.; Berindan-Neagoe, I.; Therrien, B. Synthesis, anticancer activity, and genome profiling of thiazolo arene ruthenium complexes. J. Med. Chem. 2015, 58, 8475-8490. [CrossRef]

31. Mühlgassner, G.; Bartel, C.; Schmid, W.F.; Jakupec, M.A.; Arion, V.B.; Keppler, B.K. Biological activity of ruthenium and osmium arene complexes with modified paullones in human cancer cells. J. Inorg. Biochem. 2012, 116, 180-187. [CrossRef] [PubMed]

32. Seršen, S.; Kljun, J.; Kryeziu, K.; Panchuk, R.; Alte, B.; Körner, W.; Heffeter, P.; Berger, W.; Turel, I. Structure-related mode-of-action differences of anticancer organoruthenium complexes with $\beta$-diketonates. J. Med. Chem. 2015, 58, 3984-3996. [CrossRef]

33. Habtemariam, A.; Melchart, M.; Fernandez, R.; Parsons, S.; Oswald, I.D.H.; Parkin, A.; Fabbiani, F.P.A.; Davidson, J.E.; Dawson, A.; Aird, R.E.; et al. Structure-activity relationships for cytotoxic ruthenium(II) arene complexes containing N,N-, N,O-, and O,O-chelating ligands. J. Med. Chem. 2006, 49, 6858-6868. [CrossRef] [PubMed]

34. Vock, C.A.; Renfrew, A.K.; Scopelliti, R.; Juillerat-Jeanneret, L.; Dyson, P.J. Influence of the diketonato ligand on the cytotoxicities of $\left[\mathrm{Ru}\left(\eta^{6}-p \text {-cymene)-( } \mathrm{R}_{2} \mathrm{acac}\right)(\mathrm{PTA})\right]^{+}$complexes (PTA = 1,3,5-triaza-7-phosphaadamantane). Eur. J. Inorg. Chem. 2008, 1661-1671. [CrossRef]

35. Pettinari, R.; Marchetti, F.; Condello, F.; Pettinari, C.; Lupidi, G.; Scopelliti, R.; Mukhopadhyay, S.; Riedel, T.; Dyson, P.J. Ruthenium(II)-arene RAPTA type complexes containing curcumin and bisdemethoxycurcumin display potent and selective anticancer activity. Organometallics 2014, 33, 3709-3715. [CrossRef]

36. Caruso, F.; Rossi, M.; Benson, A.; Opazo, C.; Freedman, D.; Monti, E.; Gariboldi, M.B.; Shaulky, J.; Marchetti, F.; Pettinari, R.; et al. Ruthenium-arene complexes of curcumin: X-ray and density functional theory structure, synthesis, and spectroscopic characterization, in vitro antitumor activity, and DNA docking studied of ( $p$-cymene)Ru(curcuminato)chloro. J. Med. Chem. 2012, 55, 1072-1081. [CrossRef]

37. Gatti, A.; Habtemariam, A.; Romero-Canelón, I.; Song, J.I.; Heer, B.; Clarkson, G.J.; Rogolino, D.; Sadler, P.J.; Carcelli, M. Halfsandwich arene ruthenium(II) and osmium(II) thiosemicarbazone complexes: Solution behavior and antiproliferative activity. Organometallics 2018, 37, 891-899. [CrossRef]

38. Basto, A.P.; Anghel, N.; Rubbiani, R.; Müller, J.; Stibal, D.; Giannini, F.; Süss-Fink, G.; Balmer, V.; Gasser, G.; Furrer, J.; et al. Targeting of the mitochondrion by dinuclear thiolato-bridged arene ruthenium complexes in cancer cells and in the apicomplexan parasite Neospora caninum. Metallomics 2019, 11, 462-474. [CrossRef] [PubMed]

39. Jones, R.A.; Katritzky, A.R. N-oxides and related compounds. Part XVII. The tautomerism of mercapto- and acylamino-pyridine 1-oxides. J. Chem. Soc. 1960, 2937-2942. [CrossRef]

40. Kljun, J.; Anko, M.; Traven, K.; Sinreih, M.; Pavlič, R.; Peršič, Š.; Ude, Ž.; Codina, E.E.; Stojan, J.; Lanišnik, R.T.; et al. Pyrithionebased ruthenium complexes as inhibitors of aldo-keto reductase $1 \mathrm{C}$ enzymes and anticancer agents. Dalton Trans. 2016, 45 , 11791-11800. [CrossRef]

41. Kladnik, J.; Kljun, J.; Burmeister, H.; Ott, I.; Romero-Canelón, I.; Turel, I. Towards identification of essential structural elements of organoruthenium(II)-pyrithionato complexes for anticancer activity. Chem. Eur. J. 2019, 25, 14169-14182. [CrossRef] [PubMed]

42. Marković, K.; Milačič, R.; Marković, S.; Kladnik, J.; Turel, I.; Ščančar, J. Binding kinetics of ruthenium pyrithione chemotherapeutic candidates to human serum proteins studied by HPLC-ICP-MS. Molecules 2020, 25, 1512. [CrossRef] [PubMed]

43. Ristovski, S.; Uzelac, M.; Kljun, J.; Lipec, T.; Uršič, M.; Zemljič, J.Š.; Žužek, M.C.; Trobec, T.; Frangež, R.; Sepčić, K.; et al. Organoruthenium prodrugs as a new class of cholinesterase and glutathione-S-transferase inhibitors. ChemMedChem 2018, 13, 2166-2176. [CrossRef] [PubMed]

44. Kladnik, J.; Ristovski, S.; Kljun, J.; Defant, A.; Mancini, I.; Sepčić, K.; Turel, I. Structural isomerism and enhanced lipophilicity of pyrithione ligands of organoruthenium(II) complexes increase inhibition on AChE and BuChE. Int. J. Mol. Sci. 2020, 21, 5628. [CrossRef]

45. Daigle, D.J.; Decuir, T.J.; Robertson, J.B.; Darensbourg, D.J. 1,3,5-Triaz-7-phosphatricyclo[3.3.1.13,7]decane and derivatives. In Inorganic Syntheses; Darensbourg, M.Y., Ed.; John Wiley \& Sons, Inc.: Hoboken, NJ, USA, 1998; Volume 32, pp. 40-45.

46. Dolomanov, O.V.; Bourhis, L.J.; Gildea, R.J.; Howard, J.A.K.; Puschmann, H. OLEX2: A complete structure solution, refinement and analysis program. J. Appl. Crystallogr. 2009, 42, 339-341. [CrossRef]

47. Sheldrick, G.M. SHELXT-Integrated space-group and crystal-structure determination. Acta Crystallogr. A 2015, 71, 3-8. [CrossRef]

48. Martin, D.P.; Blachly, P.G.; McCammon, J.A.; Cohen, S.M. Exploring the influence of the protein environment on metal-binding pharmacophores. J. Med. Chem. 2014, 57, 7126-7135. [CrossRef] 
49. Lam, N.Y.S.; Truong, D.; Burmeister, H.; Babak, M.V.; Holtkamp, H.U.; Movassaghi, S.; Ayine-Tora, D.M.; Zafar, A.; Kubanik, M.; Oehninger, L.; et al. From catalysis to cancer: Toward structure-activity relationships for benzimidazol-2-ylidene-derived $\mathrm{N}$-heterocyclic-carbene complexes as anticancer agents. Inorg. Chem. 2018, 57, 14427-14434. [CrossRef]

50. Oehninger, L.; Alborzinia, H.; Ludewig, S.; Baumann, K.; Wölfl, S.; Ott, I. From catalysts to bioactive organometallics: Do Grubbs catalysts trigger biological effects? ChemMedChem 2011, 6, 2142-2145. [CrossRef]

51. Schatzschneider, U.; Niesel, J.; Ott, I.; Gust, R.; Alborzinia, H.; Wolfl, S. Cellular uptake, cytotoxicity, and metabolic profiling of human cancer cells treated with ruthenium(II) polypyridyl complexes $\left[\mathrm{Ru}(\mathrm{bpy})_{2}(\mathrm{~N}-\mathrm{N})\right] \mathrm{Cl}_{2}$ with $\mathrm{N}-\mathrm{N}=\mathrm{bpy}, \mathrm{phen}, \mathrm{dpq}$, dppz, and dppn. ChemMedChem 2008, 3, 1104-1109. [CrossRef]

52. Pizarro, A.M.; Habtemariam, A.; Sadler, P.J. Activation mechanisms for organometallic anticancer complexes. In Medicinal Organometallic Chemistry; Jaouen, G., Metzler-Nolte, N., Eds.; (Topics in Organometallic Chemistry); Springer: Berlin, Germany, 2010; Volume 32, pp. 21-56. [CrossRef]

53. Briš, A.; Jašik, J.; Turel, I.; Roithova, J. Anti-cancer organoruthenium(II) complexes and their interactions with cysteine and its analogues. A mass-spectrometric study. Dalton Trans. 2019, 48, 2626-2634. [CrossRef] [PubMed]

54. Sheng, Y.; Hou, Z.; Cui, S.; Cao, K.; Yuan, S.; Sun, M.; Kljun, J.; Huang, G.; Turel, I.; Liu, Y. Covalent versus noncovalent binding of ruthenium $\eta^{6}-p$-cymene complexes to zinc-finger protein NCp7. Chem. Eur. J. 2019, 25, 12789-12794. [CrossRef] [PubMed]

55. Namiecińska, E.; Sadowska, B.; Więckowska-Szakiel, M.; Dołęga, A.; Pasternak, B.; Grazul, M.; Budzisz, E. Anticancer and antimicrobial properties of novel $\eta^{6}$-p-cymene ruthenium(II) complexes containing a N,S-type ligand, their structural and theoretical characterization. RSC Adv. 2019, 9, 38629-38645. [CrossRef]

56. Oehninger, L.; Stefanopoulou, M.; Alborzinia, H.; Schur, J.; Ludewig, S.; Namikawa, K.; Muñoz-Castro, A.; Köster, R.W.; Baumann, K.; Wölfl, S.; et al. Evaluation of arene ruthenium(II) $N$-heterocyclic carbene complexes as organometallics interacting with thiol and selenol containing biomolecules. Dalton Trans. 2013, 42, 1657-1666. [CrossRef] [PubMed]

57. Demoro, B.; de Almeida, R.F.M.; Marques, F.; Matos, C.P.; Otero, L.; Pessoa, J.C.; Santos, I.; Rodriguez, A.; Moreno, V.; Lorenzo, J.; et al. Screening organometallic binuclear thiosemicarbazone ruthenium complexes as potential anti-tumour agents: Cytotoxic activity and human serum albumin binding mechanism. Dalton Trans. 2013, 42, 7131-7146. [CrossRef]

58. Mitra, R.; Das, S.; Shinde, S.V.; Sinha, S.; Somasundaram, K.; Samuelson, A.G. Anticancer activity of hydrogen-bond-stabilized half-sandwich $\mathrm{Ru}^{\mathrm{II}}$ complexes with heterocycles. Chem. Eur. J. 2012, 18, 12278-12291. [CrossRef]

59. Needham, R.J.; Sanchez-Cano, C.; Zhang, X.; Romero-Canelón, I.; Habtemariam, A.; Cooper, M.S.; Meszaros, L.; Clarkson, G.J.; Blower, P.J.; Sadler, P.J. In-cell activation of organo-osmium(II) anticancer complexes. Angew. Chem. Int. Ed. 2017, 56, 1017-1020. [CrossRef]

60. Chow, M.J.; Ang, W.H. Organoruthenium(II)-arene complexes: Structural building blocks for anticancer drug discovery. In Inorganic and Organometallic Transition Metal Complexes with Biological Molecules and Living Cells; Lo, K.K.W., Ed.; Elsevier Academic Press Inc: San Diego, CA, USA, 2017; pp. 119-146.

61. Boivin, M.; Lane, D.; Piché, A.; Rancourt, C. CA125 (MUC16) tumor antigen selectively modulates the sensitivity of ovarian cancer cells to genotoxic drug-induced apoptosis. Gynecol. Oncol. 2009, 115, 407-413. [CrossRef] [PubMed]

62. Furlong, M.T.; Hough, C.D.; Sherman-Baust, C.A.; Pizer, E.S.; Morin, P.J. Evidence for the colonic origin of ovarian cancer cell line SW626. J. Natl. Cancer Inst. 1999, 91, 1327-1328. [CrossRef]

63. Puckett, C.A.; Ernst, R.J.; Barton, J.K. Exploring the cellular accumulation of metal complexes. Dalton Trans. 2010, 39, 1159-1170. [CrossRef]

64. Renfrew, A.K. Transition metal complexes with bioactive ligands: Mechanisms for selective ligand release and applications for drug delivery. Metallomics 2014, 6, 1324-1335. [CrossRef] [PubMed]

65. Zhang, Y.; Tao, L.; Fan, L.X.; Huang, K.; Luo, H.M.; Ge, H.; Wang, X.Y.; Wang, Q. Cx32 mediates cisplatin resistance in human ovarian cancer cells by affecting drug efflux transporter expression and activating the EGFR-Akt pathway. Mol. Med. Rep. 2019, 19, 2287-2296. [CrossRef] [PubMed]

66. Bugarcic, T.; Novakova, O.; Halamikova, A.; Zerzankova, L.; Vrana, O.; Kasparkova, J.; Habtemariam, A.; Parsons, S.; Sadler, P.J.; Brabec, V. Cytotoxicity, cellular uptake, and DNA interactions of new monodentate ruthenium(II) complexes containing terphenyl arenes. J. Med. Chem. 2008, 51, 5310-5319. [CrossRef] [PubMed]

67. Scolaro, C.; Chaplin, A.B.; Hartinger, C.G.; Bergamo, A.; Cocchietto, M.; Keppler, B.K.; Sava, G.; Dyson, P.J. Tuning the hydrophobicity of ruthenium(II)-arene (RAPTA) drugs to modify uptake, biomolecular interactions and efficacy. Dalton Trans. 2007, 43, 5065-5072. [CrossRef]

68. Flagg, E.W.; Coates, R.J.; Jones, D.P.; Eley, J.W.; Gunter, E.W.; Jackson, B.; Greenberg, R.S. Plasma total glutathione in humans and its association with demographic and health-related factors. Br. J. Nutr. 1993, 70, 797-808. [CrossRef]

69. Arner, E.S.J.; Holmgren, A. The thioredoxin system in cancer. Semin. Cancer Biol. 2006, 16, 420-426. [CrossRef]

70. Nguyen, P.; Awwad, R.T.; Smart, D.D.K.; Spitz, D.R.; Gius, D. Thioredoxin reductase as a novel molecular target for cancer therapy. Cancer Lett. 2006, 236, 164-174. [CrossRef]

71. Sasada, T.; Iwata, S.; Sato, N.; Kitaoka, Y.; Hirota, K.; Nakamura, K.; Nishiyama, A.; Taniguchi, Y.; Takabayashi, A.; Yodoi, J. Redox control of resistance to cis-diamminedichloroplatinum (II) (CDDP)—Protective effect of human thioredoxin against CDDP-induced cytotoxicity. J. Clin. Investig. 1996, 97, 2268-2276. [CrossRef]

72. Marzano, C.; Gandin, V.; Folda, A.; Scutari, G.; Bindoli, A.; Rigobello, M.P. Inhibition of thioredoxin reductase by auranofin induces apoptosis in cisplatin-resistant human ovarian cancer cells. Free Radic. Biol. Med. 2007, 42, 872-881. [CrossRef] 
73. Redza-Dutordoir, M.; Averill-Bates, D.A. Activation of apoptosis signalling pathways by reactive oxygen species. Biochim. Biophys. Acta 2016, 1863, 2977-2992. [CrossRef]

74. Ryter, S.W.; Kim, H.P.; Hoetzel, A.; Park, J.W.; Nakahira, K.; Wang, X.; Choi, A.M.K. Mechanisms of cell death in oxidative stress. Antioxid. Redox Signal. 2007, 9, 49-89. [CrossRef]

75. Jungwirth, U.; Kowol, C.R.; Keppler, B.K.; Hartinger, C.G.; Berger, W.; Heffeter, P. Anticancer activity of metal complexes: Involvement of redox processes. Antioxid. Redox Signal. 2011, 15, 1085-1127. [CrossRef]

76. Coverdale, J.P.C.; Bridgewater, H.E.; Song, J.I.; Smith, N.A.; Barry, N.P.E.; Bagley, I.; Sadler, P.J.; Romero-Canelón, I. In vivo selectivity and localization of reactive oxygen species (ROS) induction by osmium anticancer complexes that circumvent platinum resistance. J. Med. Chem. 2018, 61, 9246-9255. [CrossRef]

77. Chen, J.C.; Zhang, Y.; Jie, X.M.; She, J.; Dongye, G.Z.; Zhong, Y.; Deng, Y.Y.; Wang, J.; Guo, B.Y.; Chen, L.M. Ruthenium(II) salicylate complexes inducing ROS-mediated apoptosis by targeting thioredoxin reductase. J. Inorg. Biochem. 2019, 193, 112-123. [CrossRef] [PubMed]

78. Li, W.; Jiang, G.B.; Yao, J.H.; Wang, X.Z.; Wang, J.; Han, B.J.; Xie, Y.Y.; Lin, G.J.; Huang, H.L.; Liu, Y.J. Ruthenium(II) complexes: DNA-binding, cytotoxicity, apoptosis, cellular localization, cell cycle arrest, reactive oxygen species, mitochondrial membrane potential and western blot analysis. J. Photochem. Photobiol. B 2014, 140, 94-104. [CrossRef] [PubMed]

79. Liou, G.Y.; Storz, P. Reactive oxygen species in cancer. Free Radic. Res. 2010, 44, 479-496. [CrossRef]

80. Bolitho, E.M.; Coverdale, J.P.C.; Bridgewater, H.E.; Clarkson, G.J.; Quinn, P.D.; Sanchez-Cano, C.; Sadler, P.J. Tracking reactions of asymmetric organo-osmium transfer hydrogenation catalysts in cancer cells. Angew. Chem. Int. Ed. 2021, 60, 6462-6472. [CrossRef] [PubMed]

81. Bragado, P.; Armesilla, A.; Silva, A.; Porras, A. Apoptosis by cisplatin requires p53 mediated p38 alpha MAPK activation through ROS generation. Apoptosis 2007, 12, 1733-1742. [CrossRef]

82. Rosell, R.; Mendez, P.; Isla, D.; Taron, M. Platinum resistance related to a functional NER pathway. J. Thorac. Oncol. 2007, 2, 1063-1066. [CrossRef]

83. de Carvalho, N.C.; Neves, S.P.; Dias, R.B.; Valverde, L.D.F.; Sales, C.B.S.; Rocha, C.A.G.; Soares, M.B.P.; dos Santos, E.R.; Oliveira, R.M.M.; Carlos, R.M.; et al. A novel ruthenium complex with xanthoxylin induces S-phase arrest and causes ERK1/2-mediated apoptosis in HepG2 cells through a p53-independent pathway. Cell Death Dis. 2018, 9, 79. [CrossRef] 